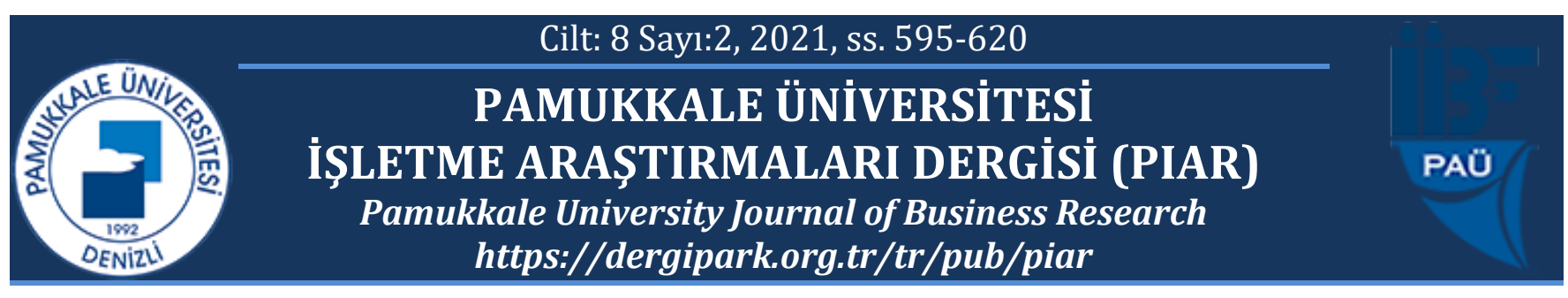

\title{
İflâs Dışı Konkordato Bağlamında Konkordato Mühleti Verilmesinin Alacaklılar, Sözleşmeler ve Borçlu Bakımından Doğurduğu Sonuçlar
}

\author{
Consequences of Giving the Peremptory Respite in the Context of Non- \\ Bankruptcy Concordat in Terms of Creditors, Contracts and Debtors
}

\section{Fikret Sami TIYYEK ${ }^{*}$}

\author{
1 Pamukkale Üniversitesi, İ̈BF, İşletme Bölümü Ticaret Hukuku Anabilim Dalı, ftiyek@pau.edu.tr, \\ https://orcid.org/0000-0002-6755-066X \\ * Yazışılan Yazar/Corresponding author
}

Makale Geliş/Received: 11.11.2021

Makale Kabul/Accepted: 20.12.2021

\begin{abstract}
Öz
Konkordato, vadesi gelmiş olmasına rağmen, borçlarını ödemekte güçlük çeken borçlular için imkan sunan bir hukuki kurumdur. Konkordatoya ilişkin hükümler İcra ve Iflas Kanunu'nda yer almaktadır.

Konkordatoya ilişkin süreçte, yetkili asliye ticaret mahkemesi, borçlu, alacaklılar ve konkordato komiseri etkili olur. Özellikle ticari işletmelerin iflastan kurtarılması ve borçlunun durumunun iyileştirilmesine yarayan konkordatonun önemli sonuçları vardır. Konkordato talebi üzerine, mahkemece konkordato mühletine ilişkin karar (geçici ve kesin mühlet) verilir. Mühlet kararının birtakım sonuçlar vardır. Bu sonuçlar, alacaklılar, borçlu ve sözleşmeler bakımından ortaya çıkar.

Çalışmanın konusunu da İcra ve Iflas Kanunu'nun 295 ve devammdaki maddelerde hüküm altına alınmıs olan konkordato mühletine ilişkin sonuçlar, oluşturmaktadır. Konkordato mühletinin sonuçlarına ilişkin hükümler, uygulamada ortaya çıkan sorunlar ve doktrindeki görüşlere de yer verilmiştir. Ayrica, konkordato mühleti verilmesi, bu karara karşı kanun yollarına başvurulması ve konkordatonun tasdik edilmesine kadar mühlet kararıyla ilgili diğer hususlara değinilmiştir.
\end{abstract}

Anahtar kelimeler: Konkordato, konkordato mühleti, mühletin sonuçları

JEL kodları: K15, K19, K35, K40

\begin{abstract}
Concordat is a legal institution for debtors who have difficulties in paying their debts, even though they are due. Provisions regarding the concordat are included in the Code of Enforcement and Bankruptcy.

In the process of concordat, the authorized commercial court of first instance, debtor, creditors and concordat commissioner are effective. Concordat, which is especially useful for saving commercial enterprises from bankruptcy and improving the situation of the debtor, has important consequences. Upon the request of the concordat, the court decides on the respite of concordat (temporary and final). The respite decision has a number of consequences. These consequences arise in terms of creditors, debtors and contracts.

The subject of the study is the results regarding the concordat deadline, which is stipulated in Article 295 and the following articles of the Code of Enforcement and Bankruptcy. The provisions regarding the results of the concordat deadline, the problems arising in practice and the views in the doctrine are also included. In addition, other issues related to the respite decision until the concordat deadline, the legal remedies against this decision and the approval of the concordat are mentioned.
\end{abstract}

Keywords: Concordat, respite of concordat, consequences of respite

JEL codes: K15, K19, K35, K40 


\section{GİRIŞ}

Konkordato kurumu, ekonomik ve ticari hayatı son derece olumsuz biçimde etkileyen iflasları önlemeye hizmet eden, ekonomik istikrarın gerçekleştirilmesine katkı sağlayan ve ekonomik ihtiyaçları gideren bir kurumdur (Yılmaz, 2014: 733; Taşpınar Ayvaz, 2005: 197; Arslan vd., 2020: 565). Doktrindeki tanımlardan yola çıkılarak konkordato, dürüst (Tanrıver, 1993: 3; Kuru, 2016: 680; Kale, 2015: 273; Atalı vd. 2020: 633-634; Saraç, 2019: 2, 3, 4$)^{1}$ bir borçlunun, borçlarının ödenebilmesi amacıyla başlatılan ve kanunda öngörülen usuller çerçevesinde onaylanıp yürürlüğe sokularak borçlunun süre kazanmasını ya da borçlarının indirime tabi tutularak ödenmesine yarayan bir hukuki kurum; bir iyileştirme aracı olarak tanımlanabilir (Arslan vd., 565; Pekcanitez vd., 2019: 465). Bununla beraber, hukukumuzda oldukça eski sayılabilecek bir geçmişe sahip olmasına rağmen, çeşitli sebeplerle işlemez hale gelmiş/getirilmiştir. Nitekim, yakın zamana kadar konkordato, hem uygulanma kabiliyetinin düşüklüğ̈̈ hem de iflasın ertelenmesi kurumunun günlük ihtiyaçlara daha fazla katkı sağlaması sebepleriyle uygulamada ve doktrinde adeta unutulmuş bir kurum konumunda bulunmaktayd $\mathrm{r}^{2}$. Yine, İcra ve İflas Kanunu'na sonradan eklenen iflasın ertelenmesine ilişkin hükümlerin yaygın olarak uygulanması ve kanun koyucunun konkordato kurumunun işlemesine yönelik isabetli adımlar atmaması sebebiyle merî olsa da uygulanmayan bir kurum haline gelmişti. Adeta hayalet bir kurum haline gelen konkordatonun canlandırılması amacıyla, 28.2.2018 günlü ve 7101 sayılı İcra ve İflâs Kanunu ve Bazı Kanunlarda Değişiklik Yapılması Hakkında Kanun (RG., 15.3.2018, Sa.: 30361) çıkarılmıştır. Bu Kanun, bilhassa artık işlemez hale gelmiş bulunan adî konkordatoya ilişkin hükümlere işlerlik kazandırılması ve sık sık kötüye kullanıldığı ifade edilen iflasın ertelenmesi kurumunu kaldırarak ticarî hayatın devamının önünde yer alan engellerin ve eksikliklerin giderilmesi noktasında işlev gören bir kanun olarak hayatımıza girmiştir. Kanun'un geneli ve İcra ve İflas Kanunu'nu değiştiren hükümlerine bakıldığında, sistematik ve içerik olarak İsviçre İcra ve İflas Kanunu'ndaki düzenlemeler ve değişikliklerin esas alınarak hazırlanan bir kanun olduğu söylenebilir (Budak ve Tunç Yücel, 2015: 28-34). Bu itibarla, doktrindeki önerilere paralel olarak, mühlet sürelerinin düzenlenmesi, geçici mühlete ilişkin yeni düzenleme yapılması ve geçici konkordato komiseri atanması (Tanrıver, 2005: 339), icra mahkemesi ve ticaret

\footnotetext{
${ }^{1}$ İcra ve İflas Kanunu'nun 7101 sayılı Kanun ile değişiklik yapılmadan önceki halinde yer alan "konkordato talebinin nazara alınması şartları başlıklı 286. maddesinin son fıkrasında, 4949 sayılı İ́ra ve İflas Kanunu'nda Değişiklik Yapılmasına Dair Kanun ile yapılan değişiklik sonucunda "dürüstlük" koşulu kaldırılmıştı. Bu sebeple, "dürüstlük" koşuluna, yeni hükümlerle de konkordatonun tasdik şartları arasında yer verilmediği için borçlunun dürüst olmasının aranmayacağ1 yönündeki görüş için bkz.: (Pekcanitez ve Erdönmez, Kitap: 130). İzmir Bölge Adliye Mahkemesi 17. Hukuk Dairesi de 13.6.2019 günlü ve E.2019/886, K.2019/1166 sayılı kararında, “....kira, doğal gaz, işçi alacakları gibi işyerinin devamı için gerekli bedellerinin ödenmemesi ve bir kısım borçların davacı tarafindan alacak ve borç kayıtlar arasında gösterilmemesi hali tespit edildiğinden, konkordato talebinde bulunanın iyi niyetli olmadığııın kabulü gerektiğini belirtmiştir. TMK.2 maddesi gereğince iyiniyet şartları her dava için değerlendirilecek ise de, konkordato talebi için davacı borçlunun borçlarını ödeme zorluğu içine düşmesi aranacă̆ından, ödenemeyen kira veya sair borçlar nedeniyle, konkordato talebinde bulunan borçlu/davacının iyiniyetli olmadı̆̆ı yönündeki tespit ve gerekçe yerinde olmamıştır..." şeklinde hüküm kurmuştur. Kanaatimizce, dürüstlük koşulu, maddi hukukta yer alan iyiniyet kavramı ve medeni yargılama hukukumuz bağlamında da işlev gören dürüstlük kuralı çerçevesinde, konkordatoya başvuru ve mühlet talebi bakımından da dikkate alınmalıdır.

2 Öyle ki, Yükseköğretim Kurulu Başkanlığı Tez Merkezi internet sayfasından erişilebilen, 1991 yılı ile 2019 yılı arasında yazılmış ve tez adı "konkordato" ifadesini içeren tezlerin sayısı, oldukça azdır.
} 
mahkemesi arasındaki gidip gelmelerin önlenmesi gibi konularda, iyileştirmeler/yenilikler yapılmıştır.

Konkordato, tabi olduğu hükümlere göre, mahkeme dışı ve mahkeme içi konkordato; içeriğine göre, alacağın belirli bir vadeye yayılarak ödenmesini konu alan vade konkordatosu, alacağın belirli bir kısmından vazgeçilerek yapılan yüzde konkordatosu ve hem alacağın belirli bir kısmından indirim yapılan hem de ödeme süresi uzatılan karma konkordato; yapıldığı zamana göre iflas dışı ve iflas içi konkordato gibi ayrımlara tabi tutulmaktadır (Tanrıver, 1993: 8-24; Arslan vd., 2020: 566; Atalı vd., 2020: 621-622). Mahkeme dışı konkordato, borçlu ve alacaklıların anlaşmasıyla herhangi bir resmi makamın katılımı olmaksızın, özel hukuk kuralları çerçevesinde yapılırken, mahkeme içi konkordato, İcra ve İflas Kanunu'nda düzenlenen ve bizim de hükümlerine işaret edeceğimiz resmi konkordato türüdür. Bunların yanında, iflas sürecinden önce, iflasa tabi olmayan kişilerin de başlatıp devam ettirebileceği adi konkordato süreci ile hakkında iflas kararı verilmiş borçlunun başvurabileceği iflas içi konkordato prosedürü mevcuttur. İcra ve İflas Kanunu'nda düzenlenen ve geniş ölçekte kendisine yer verilen konkordato türü, iflas dışı konkordatodur. Bunlar dışındaki malvarlığının terki suretiyle konkordatoda ise, alacaklıların, borçlunun malvarlıkları üzerinde tasarrufta bulunabilmesi ya da malların tümünü satma ve devretme yetkisinin verilmesi söz konusudur (Arslan vd., 2020: 566). Bu çalışma kapsamında yapılacak açıklamalar, iflas dışı konkordato yani adi konkordato temel alınarak yapılacaktır.

İcra ve İflas Kanunu'nda önemli ve geniş çaplı değişiklikler getiren hükümlerden, konkordato mühletinin sonuçları ve konkordatonun verilmesinden sonra yapılacak iş ve işlemler, bu çalışmanın konusunu teşkil etmektedir. Çalışmada öncelikle, konkordato talebi üzerine verilecek geçici mühlete ve kesin mühlete karşı gidilebilecek kanun yolları irdelenecek, 9.6.2021 tarihli ve 7327 sayılı İcra ve İflâs Kanunu ile Bazı Kanunlarda Değişiklik Yapılmasına Dair Kanun ile getirilen yenilikler de gözetilerek her iki mühlet kararının sonuçları, alacaklılar, sözleşmeler ve borçlu bakımından ayrı ayrı inceleme konusu yapılacaktır. Son olarak da, konkordato mühleti verilmesi ile tasdik aşamasına kadar geçen süreçte, özellik arz eden noktalara değinilecektir. Tüm bunlar yapılırken, sorunlu olduğu tespit edilen noktalarda yargı kararlarına yer verilecek ve çözüm getirilebilmesi açısından görüş belirtilecektir.

\section{KONKORDATO TALEBİ VE İNCELENMESI}

\subsection{Genel Olarak}

7101 sayılı Kanun, 15.3.2018 tarihi itibariyle yürürlüğe girmiş ve bilhassa İcra ve İflas Kanunu'nun $285 \mathrm{vd}$. maddelerinde önemli yenilikler getirmiştir. Bunların içinde konkordato mühletine ilişkin olan değişiklikler ve konkordatonun tasdiki evresine kadar olan sürece ilişkin değişiklikler de yer almaktadır. Bahsi geçen hükümlerden bazıları, bir kez de 9.6.2021 günlü ve 7327 sayılı Kanun ile değişikliğe uğramıştır. Bu itibarla, öncelikle konkordato talebi üzerine geçici mühlet ve sonrasında kesin mühlet aşamalarıyla bunlara ilişkin olarak başvurulabilecek kanun yollarına değinilmesi gerekmektedir.

\subsection{Konkordato Mühleti Verilmesi}

Konkordato, hem alacaklı hem borçlu tarafından, iflasa tabi olan borçlunun muamele merkezinin bulunduğu ya da merkezi yurtdışındaysa Türkiye'deki merkez şubesinden; 
iflasa tabi olmayan borçlunun ise yerleşim yerindeki asliye ticaret mahkemesinden istenebilir (İ̈K m.285, III). Borçlarını, vadesi gelmesine rağmen ödemekte güçlük çeken yahut vaktinde ödeyememe ihtimaliyle karşı karşıya olan bir borçlu, vade veya tenzilat konkordatosu talep edebilir. Borçların ödenmesi yerine muhtemel bir iflastan kurtulmak için de konkordato kurumuna başvurulabilir (İ̈K m.285, I). Bununla birlikte, borçlunun iflası talebinde bulunmaya ehil olan alacaklıların da gerekçeli dilekçeleriyle birlikte konkordato sürecinin başlatılmasını istemeleri mümkündür (İ̈K m.285, II). Konkordato talep edilirken ibraz edilmesi gereken belgeler İcra ve İflas Kanunu'nun 286. maddesinde gösterilmiştir ${ }^{3}$. Bu belgelerin eksiksiz bir biçimde sunulduğunu tespit eden mahkeme, geçici mühlet (Simil, 2020: 34 vd.) kararını verecektir. Örnek vermek gerekirse, borca batıklık bilançosunun, şirketin tüm aktiflerini içermesi gerektiğinden, gayri maddi hak olarak kabul edilen markaya ilişkin defter değeri gösterilebilir. Nitekim, konkordato tasdiki aşamasında, şirkete ait marka/markaların bedellerinin belirlenmeden borca batıklığa ilişkin karar verilmesi, İstanbul Bölge Adliye Mahkemesi 45. Hukuk Dairesi'nin 7.7.2021 günlü ve E.2021/62, K.2021/741 sayılı kararı ile bozma sebebi addedilmiştir ${ }^{4}$.

Geçici mühlet kararının verilmesiyle birlikte, 297. maddenin ikinci fikrasında yer alan borçlunun tasarruf yetkisine ilişkin kısıtlamalar devreye girer ve mahkemece gerekli görülen diğer bazı tedbirler alınır (İ̈K m.287, I). Geçici mühlete karar veren mahkeme, konkordatonun başarılı olma ihtimalini takip etmesi amacıyla kural olarak bir kişiyi (gerekli görülürse üç kişiyi) geçici konkordato komiseri olarak atar (İ̈K m.287, III; Sarısözen, 2021: 201) ve geçici mühlet kararı, başta ticaret sicili gazetesi ve Basın İlan Kurumu'nun sitesi olmak üzere ilgili (İKK m.288, II) yerlerde ilan edilir. Doktrinde, konkordato talebini alan mahkemenin, geçici konkordato komiseri atamasının İsviçre İcra ve İflas Kanunu'ndan farklı olarak zorunlu tutulduğu ve üç komiser atanmasının konkordato sürecindeki masrafları artırabileceği, bunun da alacaklılar açısından olumsuz olacağına dikkat çekilmiştir (Pekcanitez ve Erdönmez, 2018: 119).

Geçici mühletin süresi kural olarak üç ay olmakla birlikte, toplam beş ayı geçmeyecek şekilde, sürenin dolmasından önce, borçlu ya da geçici komiserin talebiyle iki ay daha uzatılabilir $^{5}$ (İ̈K m.287, IV; Özekes, 2018: 77-78). Konkordato talep eden borçlunun ya da

\footnotetext{
${ }^{3} \mathrm{Bu}$ maddede işaret edilen bazı belgeler, konkordato ön projesi, borçlunun malvarlığı durumunu gösteren belgeler, bilançolar, ticari defterler, alacak miktarlarıyla birlikte alacaklıların listesi, alacaklıların eline geçecek muhtemel miktarı gösterir tablo ve bağımsız denetim kuruluşları tarafından hazırlanacak denetim raporu gibi belgelerdir. Birinci fıkranın (a), (b), (c), (d) ve (e) bentlerinde yer alan belgeler dışında, mahkemenin ya da komiserin, konkordato sürecinde isteyeceği başka belgelerin de sunulması zorunludur (İ̈K m.286, II). Birinci fıkranın (e) bendindeki hüküm, Kanun'un ilk halinde konkordato projesinin gerçekleşmesinin "kuvvetle muhtemel" olmasıyken, 7155 sayılı Kanun ile "makul güvence veren", "finansal analiz raporu" yerine "denetim raporu"nun eklenmesi gerektiği şeklinde değiştirilmiştir. Burada ispat ölçüsü hafifletilmiş ve böylece bilimsel veriler ışı̆̆ında hazırlanacak denetim raporunun makul oranda güvence vermesi yeterli bulunmuştur. Bu değişiklik yapılmadan önce yapılan mühlet başvurularında, değişiklikten sonraki belgelerin istenmesinin yerinde olmadığına ilişkin bkz.: İzmir BAM 17 HD., T. 6.7.2021, E.2021/914, K.2021/865. (https://lib.kazanci.com.tr/kho3/ibb/files/is-izmirbam-17hd-2021-914.htm)

${ }^{4}$ (https://lib.kazanci.com.tr/kho3/ibb/files/is-istanbulbam-45hd-2021-62.htm)

5 “...Konkordato sürecinde, dava teorisinin aksine yargılama sırasında değişen durumların da nazara alınması gerektiği gözetilerek, borçlu şirketlerin güncel durumları itibariyle, dosyaya sunulan konkordato projesinin, revize bir proje sunulması halinde sunulan revize projenin başarıya ulaşıp ulaşamayacağı konusunda, geçici komiser kurulundan yeni bir rapor
} 
alacaklının mutlak suretle katılımıyla geçici mühlet süresi içerisinde icra edilecek duruşmada (Sarıözen, 2021: 243), mahkeme, komiserin yazılı raporuna göre ve gerekirse sözlü beyanlarını da alarak konkordatonun başarıya ulaşması ${ }^{6}$ ihtimali mevcutsa, borçluya bir yıllık (gerekli görülürse bu süre altı ay daha uzatılabilir) kesin mühlet verir ${ }^{7}$. Gerekmedikçe geçici komiser ya da komiserler görevine devam ederler ve yeni komiser ataması yapılmaz (İK m.289, III; Özekes, 2018: 80). Konkordato komiseri, dosyayı teslim alır ve konkordatonun tasdik edilmesine kadar gerekli iş ve işlemleri yürüttükten sonra mahkemeye iade eder. Komiserin görevleri, İcra ve İflas Kanunu'nun 290. maddesinde sayılmıştır. Çalışmamız bağlamında konkordato komiserinin önem arz eden görevleri, aşağıda ifade edilecek kanuni yükümlülüklerin yerine getirilmesi ve bilhassa konkordato projesinin tamamlanmasına katkıda bulunması ve borçlunun faaliyetlerine nezaret

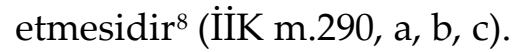

\subsection{Kanun Yolları (İİK m.293)}

İcra ve İflas Kanunu'nun 289. maddesine göre, şartların gerçekleşmesi halinde borçluya, bir yıllık kesin mühlet verilir ve aynı maddenin son fıkrası uyarınca bu karar ile mühletin uzatılması veya kesin mühletin kaldırılması (konkordatonun reddedilmesi) kararları, aynı Kanun'un 288. maddesinde belirtilen usule göre ilan edilecektir. Atıf yapılan 288. madde, esasında geçici mühletin sonuçlarıyla ilgili olup, birazdan yapacağımız açıklamalar geçici mühlet için geçerli değildir. Zira, İcra ve İflas Kanunu'nun 287. maddesinin son fikrası uyarınca, geçici mühlete ilişkin talebin kabul edilmesi, geçici komiserin görevlendirilmesi, geçici mühletin uzatılmasıyla tedbirler hakkındaki kararlar aleyhine kanun yoluna başvuru mümkün değildir. Dolayısıyla, kesin mühlet talebinin sonucunda, hangi hallerde kanun yollarına başvurulup başvurulamayacağı inceleme konusu yapılmalıdır.

Öncelikle, İcra ve İflas Kanunu'nun 293. maddesinin birinci fıkrasına göre, kesin mühlet talebinin kabulüne ve bu mühletin kaldırılmasına ilişkin taleplerin reddi kararlarına karşı, kanun yoluna başvuru imkanı bulunmamaktadır (Balcı, 2007: 113). Çünkü, konkordato

alınarak, sonucuna göre karar verilmesi gerekir..." Yargitay 23. HD., T.20.01.2021, E.2020/1165, K.2021/123. (https://lib.kazanci.com.tr/kho3/ibb/files/23hd-2020-1165.htm)

${ }^{6}$ Başarıya ulaşma kavramı, 7101 sayılı Kanun'un gerekçesinde, hakkında konkordato talep edilmiş borçlunun mali durumunun düzelmesinin mümkün olup olmadığı ya da konkordato teklifi hakkındaki tasdik şartlarının gerçekleşip gerçekleşmeyeceği şeklinde ifade edilmiştir.

7 “....̇ंcra ve İflâs Kanunu mühletin tanımını yapmamış ve hukuki niteliğini göstermemiştir. Yasa koyucunun konkordato süresi ya da mehli gibi bir kavram yerine mühlet kavramın başlangıcı ve sonu belli bir zaman dilimini ifade etmek üzere bilinçli biçimde seçtĭgi anlaşılmaktadır. Bu bağlamda mühlet bittikten sonra uzatma mümkün değildir. Somut olayda mahkemece istemci şirkete bir yıl kesin mühlet verilmiş, borçlu tarafindan mahkemenin inceleme yapmasına olanak bırakacak şekilde uzatma istenmiş ve mahkemece kesin mühlet için öngörülen süre dolduktan sonra "kesin mühletin sona ereceğ $i$ tarihten başlanarak 3 ay süreyle uzatılmasına" karar verilmiştir. Uzatma kararında uzatma süresinin başlangıcı gösterilmiş ise de sona ermiş ve hüküm ve sonuçların tamamen kaybetmiş mühletin uzatılmasına yasal olanak bulunmamaktadır. Hal böyle olunca istemci için mühlet sona erdiğinden, onun için devam eden bir konkordato prosedürünün mevcudiyetinden söz edilemez. Sonradan verilen uzatma kararlarının ve kesin mühlete bağlanmış sonuçların uygulanma kabiliyeti de bulunmamaktadır. Açıklanan nedenle, İlk derece Mahkemesi'nin kararı düzeltilerek, konkordato isteminin usulden reddine dair yeniden esas hakkında karar verilmelidir..." (Ankara Bölge Adliye Mahkemesi 23. Hukuk Dairesi, T.5.7.2021, E.2021/683, K.2021/1076). (https://ib.kazanci.com.tr/kho3/ibb/files/is-ankarabam-23hd-2021-683.htm)

8 “....aynı yasanın 290.maddesinde ise konkordato komiserinin görevleri arasında, konkordato projesinin tamamlanmasına katkıda bulunmak gibi hususların göz ardı edilmesi, konkordato komiserlerinden, davacı gerçek kişi yönünden rapor alınmamış olması yerinde değildir..." İstanbul Bölge Adliye Mahkemesi 17. HD., T.6.2.2020, E.2019/1218, K.2020/355. (https://lib.kazanci.com.tr/kho3/ibb/files/is-istanbulbam-17hd-2019-1218.htm) 
sürecinde amaç; yavaşlı̆̆ın aksine, sürecin olabildiğince basit ve çabuk işlemesidir. Bu itibarla konkordato talebinin sonrasında yapılacak işlemlerin vakit alacak olması sebebiyle, geçecek sürede, hak kayıplarını en aza indirgemek amacıyla ihdas edilen geçici mühlet aşaması ile bilhassa konkordato komiserinin önemli görevleri yerine getirdiği, konkordatonun akıbeti hakkında olumlu ya da olumsuz bir karar verilmesi için geçecek sürede (kesin mühlet süreci içerisinde) hak kaybı olmaması ve sürecin selameti açısından bu şekilde bir düzenleme getirildiği sonucuna ulaşılabilir. Nitekim, madde gerekçesinde ${ }^{9}$ de, konkordato hakkında yapılacak kanun yolu denetiminin, kapsamlı bir biçimde konkordatonun tasdiki evresinde gerçekleştirileceğinin kabul edildiğine ve bu sebeple de mühlet süresi içerisinde yapılacak kanun yolu incelemesinin sınırlandırıldığına işaret edilmiştir.

Geçici mühlet bağlamında kanun yollarına başvurulamayacağı yönündeki kural, kesin mühlette esnetilmiş ve kesin mühlet talebi hakkında yapılacak inceleme sonucunda, sadece konkordato talebinin reddine karar verilmiş, yani iflas kararı verilmemişse, borçlu veya konkordato talep etmiş olan alacaklının, red kararının tebliğinden itibaren 10 günlük süre içerisinde bölge adliye mahkemesine başvurabileceği hüküm altına alınmıştır (Kuru, 2016: 685; İ̈K m.293, II, c.1) ${ }^{10}$. Aynı fıkranın ikinci cümlesine göre istinaf incelemesi sonucunda verilecek karar kesindir ${ }^{11}$. Şayet bölge adliye mahkemesi, ilk derece mahkemesinin kararını kaldırıp mühlet kararı verecek olursa, komiser görevlendirilmesi gibi işlemlerin yapılması amacıyla dosya ilk derece mahkemesine gönderilir (İK m.293, II, c. son; Arslan vd., 2020: 574).

Burada, istisnai olarak, asliye ticaret mahkemesinin veya istinaf mahkemesinin konkordato talebini reddetmesi ve aynı zamanda borçlunun iflasa tabi kişilerden olup da iflasına karar verilmesi halinde, bu kararlara karşı, hem istinaf hem de temyiz kanun yoluna başvurulması mümkündür. Bu hususa, aynı maddenin üçüncü fıkrasında, İcra ve İflas Kanunu'nun 164. maddesine yapılan atıfla işaret edilmiştir. Buna göre, asliye ticaret mahkemesince verilen nihai kararlara karşı, on günlük istinaf süresi vardır. Yine, bölge adliye mahkemesince verilecek karara karşı da bu kararın tebliğinden itibaren on gün içerisinde temyiz kanun yoluna başvuru mümkündür (İIKK m.164, II).

Konkordatonun onaylanması hakkındaki karar bozulursa, devam eden takipler durur ve konkordatonun reddedilmesi kararı kesinleşmedikçe, borçlu aleyhine iflas davası açılamaz (Coşkun, 2016: 4869).

\footnotetext{
${ }^{9}$ İ́ra ve İflas Kanunu ve Bazı Kanunlarda Değişiklik Yapılması Hakkında Kanun'un İcra ve İflas Kanunu'nun 293. maddesini değiştiren 21. maddesi gerekçesi.

10 İcra ve İflas Kanunu'nun eski halinde, 363. maddenin onikinci fıkrası uyarınca, konkordato mühleti hakkında icra mahkemesi kararının üzerine, 10 gün içinde, temyiz yoluna gidilmekteydi (Tanrıver, 1993: 54). 4949 sayılı Kanun ile konkordato mühletinin reddi ve mühletin kaldırılmasına ilişkin kararlar, süreci hızlandırmak için temyiz edilebilir kararlar arasından çıkarılmıştır (Balcı, 2007: 114).

${ }^{11}$ Aynı yöndeki karar için bkz.: “... Somut olayda, ilk derece mahkemesince sadece mühlet talebinin reddine karar verilmiş olup, iflasa karar verilmediğinden, bu karara karşı istinaf kanun yoluna başvurulmuş olmakla birlikte bölge adliye mahkemesince verilen karar kesin olduğu için temyiz dilekçesinin reddine karar verilmesi gerekir..." Yargitay 23. HD., T.9.5.2019, E.2019/1337, K.2019/1902. (https://lib.kazanci.com.tr/kho3/ibb/files/23hd-2019-1337.htm)
} 


\section{KONKORDATO MÜHLETINIIN SONUÇLARI}

\subsection{Genel Olarak}

Konkordato talebi üzerine verilecek olan geçici mühlet ve kesin mühlet hakkındaki kararların bir takım sonuçları vardır. Nitekim, konkordato mühleti verilmesi, hem borçlunun hem de alacaklıların haklarında belirli sınırlamalara sebep olacaktır. Mühlet kararı verildikten sonra ortaya çıkacak sınırlamalar, borçlu bakımından ve alacaklılar bakımından ayrı ayrı etkiler doğurur. Konkordatoda borçlu, icra ve iflas takibi tehditlerinden (Şahin, 2020: 214) bir anlamda kurtulur ve malvarlığının iyileşmesi, en azından korunmasi/kötüleşmemesi için müzakerelerde bulunma imkanına sahip olur. Her bir somut olaya göre, borçlunun mu menfaatinin yoksa alacaklıların menfaatinin mi korunacağ değişebilir (Ermenek ve Kartal, 2020: 496-497). İşte bu süreçteki sinırlamalar, borçlu bakımından tasarruf yetkisinin önemli ölçüde kısıtlanması ve alacaklılar bakımından ise yeni takiplerin yapılamaması, başlatılmış olan takiplerin devam ettirilememesi şeklinde karşımıza çıkar (Tanrıver, 1993: 62; Balc1, 2007: 138 vd; Arslan vd., 2020: 572).

Mühlete ilişkin kararın verilmesi ve tasdik aşamasına geçildiğinde dikkat edilmesi gereken hususlardan bir diğeri, alacaklılar arasında da bir dengenin sağlanması gerekliliğidir. Nitekim, Yargitay, 2.3.2021 tarihinde vermiş olduğu bir kararında"12, "konkordatoda, alacaklılar arasında mutlak eşitliğin sağlanması şart olmayıp, dengeli ve adil bir ödeme planı ortaya konulması, alacaklıların da buna göre tatmin edilmesinin sağlanması amaçlandığından", alacağının tamamını ya da ya da büyük bir bölümünü tahsil edecek küçük alacaklılar ile diğer alacaklılar arasında, ödeme planından kaynaklanan sebeplerle "adil ve dengeli bir şekilde tatmin edilme" ilkesinin ihlal edildiğine hükmetmiştir (Yargitay 15. HD. T. 2.3.2021, E.2021/1209, K.2021/569).

İcra ve İflas Kanunu'nda yapılan değişiklikle geçici mühlet kararının ilan edilmesi ile ortaya çıkacak sonuçlara ayrıca değinilmemiştir. Bunun yerine kesin mühlete ilişkin sonuçlara atıf yapılmakla (m.288, I) yetinildiği için (Taşpınar Ayvaz, 2005: 197), doğrudan kesin mühletin sonuçları üzerinde durmak gerekir ${ }^{13}$.

$\mathrm{Bu}$ bağlamda, kesin mühletin, alacaklılar, sözleşmeler ve borçlu bakımından sonuçları üç başlık altında irdelenecektir.

\subsection{Mühletin Alacaklılar Bakımından Sonuçları}

\subsubsection{Genel Olarak}

Konkordato mühletinin amacı, borçluya, takiplerden korunmasını sağlayacak şekilde, alacaklıların toplanması ve ilgili alacaklılarla müzakere edilerek konkordato yapılıp mahkemece onaylanmasını sağlamaktır. Verilecek olan mühletin, tasdik aşamasına kadar

\footnotetext{
12 (https://lib.kazanci.com.tr/kho3/ibb/files/15hd-2021-1209.htm)

137226 sayılı Kanun ile Covid-19 salgınının etkili olduğu süreçte tüm icra ve iflâs takiplerinin durmasına karar verilmiş, konkordato mühletinin alacaklı ve borçlu bakımından doğurduğu sonuçlar ayrık tutulmuştur. Ancak bu durum doktrinde haklı olarak eleştirilmiş, komiserin yetki ve görevleri ile konkordato mühletinin diğer sonuçlarının akıbetinin belirsiz olduğu ve konkordato mühletinin diğer süreler gibi durması gerektiğine işaret edilmiştir (Pekcanitez, 2020). (https://lib.kazanci.com.tr/kho3/ibb/files/15hd-2021-1209.htm)
} 
geçen süre boyunca işlevini yapabilmesi adına bir takım sonuçlar bağlanmıştır (Pekcanıtez vd., 2019: 468).

\subsubsection{Takip Yasağı ve Süreler Bakımından}

İcra ve İflas Kanunu'nun 294. maddesinin birinci fıkrası uyarınca, mühlet içinde borçlu aleyhine, hiçbir takip yapılamaz (6183 sayılı Amme Alacaklarının Tahsil Usulü Hakkında Kanun uyarınca gerçekleştirilen takipler dahil) ve daha önceden başlamış takipler durur, ihtiyati tedbir ile ihtiyati haciz kararları uygulanamaz. İhtiyati haciz kararı verilebilse de, bu karar icra edilemeyecektir (Şahin, 2020: 228). Bu açı hükme rağmen ihtiyati haciz ya da ihtiyati tedbire ilişkin kararın uygulanması halinde, ilgili işlem geçersiz kabul edilir (Akil, 2019a: 243). Yine, bir takip işlemiyle kesilebilen zamanaşımı ve hak düşürücü süreler de mühlet süresince işlemeyecektir (Pekcanitez vd., 2019: 469; Yılmaz, 2016: 1265; Kuru, 2016: 688; Aydemir, 2015: 44-45; Sarısözen, 2021: 353). Takip yasağının başlama anı ise, geçici konkordato mühletinin verildiği andır (Akil, 2019a: 230).

Takip yasağ1 getirilmesindeki amaç, hem borçlunun malvarlığ oranda korunması hem de konkordato projesine uygun bir biçimde sürecin nihayete erdirilmesiyle bu yapılırken de alacaklılara belirli şartlar dahilinde eşit imkanlar sunulmasıdır (Tunç Yücel, 2020: 127; Türkoğlu, 2019: 116). Nitekim, borçlunun konkordato için gerekli hazırlıkları yapabilmesi ve borçlunun işletmesinin başında bulunarak mali açıdan düzlüğe çıkabilmesi de bu takip yasağıyla mümkün olur (Akil, 2019a: 229; Sarısözen, 2021: 306).

Takip yasağına ilişkin burada belirtilen hususlar, Kanun'dan doğmaktadır. Bu sebeple de, geçici mühlet kararı verilirken ve sonrasında da mahkemece ayrıca takiplerin durmasına veya yeni takip başlatılmamasına yönelik karar alınması gerekli değildir (Tunç Yücel, 2020: 128).

Takip başlatılamama ibaresinden ne anlaşılması gerektiği konusunda ise doktrinde farklı görüşler mevcuttur. Bir görüşe göre, burada takip işlemi veya icra takip işlemi başlatılamaması anlaşılmalı ve bu itibarla takip başlatılabilmeli, ancak borçluya yönelik yapılacak icra takip işlemleri yapılamamalıdır (Arslan vd. 2020: 574; Şahin, 2020: 206-207; Akil, 2019a: 231; Uyar, 2019: 152'de yer alan görüşler;). Bizim de katıldığımız diğer görüşe göre ise, madde lafzındaki "takip" yapılamamasından, icra takip işlemleri anlaşılamaz (Tunç Yücel, 2020: 133; Türkoğlu, 2019: 152-153). Tunç Yücel, zamanaşımı ve hak düşürücü sürelerin, mühlet süresince işlemeyeceğine ilişkin hükümle bu görüşünü desteklemekte; takip başlatılsa ve dosya icra müdürlüğünde beklerken herhangi bir nedenle mühlet kalkarsa, hem alacaklının hem de icra dairesinin, derhal ödeme emri gönderilmesi konusunda önemli bir yük altında kalacağını ifade etmektedir (Tunç Yücel, 2020: 133-135). Uyar ise, konkordato mühleti içinde alacaklının takip talebinde bulunmasının gereksiz yere harç ödenmesi ve zamanaşımı sürelerinin işlemeyeceği gibi sebeplerle çoğu zaman faydasız olduğunu belirtmiştir (Uyar, 2019: 153).

Yargıtay ise, önüne gelen bir uyuşmazlıkta ${ }^{14}$, hakkında geçici mühlet kararı verilmesinden sonra başlatılan kambiyo senetlerine özgü haciz yoluyla takibin iptalini isteyen borçlunun

14 Yargitay 12. HD., T.14.6.2021, E.2021/3971, K.2021/6366. (https://lib.kazanci.com.tr/kho3/ibb/files/12hd-20213971.htm) 
talebini, "...tedbir kararında tüm takip işlemlerinin yapılmasının durdurulmasına..." karar verildiği gerekçesiyle reddeden bölge adliye mahkemesinin kararını şu gerekçeyle bozmuştur: "....Her ne kadar tedbir kararında tüm takip işlemlerinin yapılmasının durdurulmasına denilmişse de ayn kararda geçici mühlet içinde İcra ve İflas Kanunu'nun 294, 295, 296 ve 297 maddelerinin uygulanmasina yönelik hükme de yer verildiği, İcra ve İflas Kanunu'nun 294/1. maddesinin açık hükmü karşısında takip işlemlerinin durdurulmasına dair tedbir ara kararının hüküm ifade etmeyeceği açıktır. Dolayısıyla bölge adliye mahkemesince; 2004 Sayılı İcra ve Íflas Kanunu'nun 294/1. maddesi gereğince mühlet içinde hiç bir takip yapılamayacağı gözetilmek suretiyle istinaf başvurusunun esastan reddine karar verilmesi gerekirken, yazll şekilde hüküm tesisi isabetsiz olup, bölge adliye mahkemesi kararının bozulması gerekmiştir...". ${ }^{15}$

Takiplerin durması, yani mühletin kaldırılması halinde alacaklıların takibe devam edebilmeleri için (Uyar, 2019: 163), konkordatonun tasdikinin kesinleşmesine ihtiyaç bulunmamaktadır (Yilmaz, 2016: 1264).

Geçici mühletin verilmesiyle birlikte borçlu aleyhine takip yasağı başlar. Bu sebeple mühletin yasal sonucu olan takip yapılmaması yasağı, mühletin sona ermesi ile birlikte derhal etkisini gösterecek ve kendiliğinden ortadan kaldırılacaktır. İstanbul Bölge Adliye Mahkemesi de 3.12.2020 günlü ve E.2020/2121, K.2020/2116 sayılı karar1 ${ }^{16}$ ile “...mahkemece geçici mühlet kaldırılmasına ră̆men, davacıların halen mühletin etkilerinden yararlanmasın sağlayacak şekilde, takip yapılmaması yasağının karar kesinleşene kadar devamının söz konusu olamayacağına hükmetmiştir...". Dolayısıyla, takip yasağı, kural olarak konkordato mühletiyle sınırlıdır. Yani, bu süre sonunda borçlu aleyhine takip yapılabilir. Ancak, İcra ve İflas Kanunu'nun 304. maddesinin ikinci fıkrasına göre, mahkemece, konkordatoya ilişkin yapılan yargılamada, kesin mühlet süresi içerisinde karar verilmesinin mümkün olmadığ kanısına varılırsa, komiserden gerekçeli bir rapor alınmasına ve konkordato hakkında karar verilinceye kadarki sürede de mühlet hükümlerinin geçerli olacağına hükmedilebilir (Akil, 2019a: 237). Mühlete ilişkin hükümlerin, konkordato hakkında karar verilinceye kadar geçerli olacağı süre en fazla altı ay olabilir.

Yine, konkordato mühletinin etkilerinin, konkordatonun bağlayıcı hale geldiği tarihe kadar devam etmesi de mümkündür (Akil, 2019a: 237). İcra ve İflas Kanunu'nun 308/c maddesinin birinci fıkrasına göre, konkordatonun bağlayıcı hale gelmesi için mahkemenin konkordato projesini tasdik etmesi gerekir. Kural, konkordatonun tasdik kararıyla bağlayıcılık kazanması olmakla birlikte, konkordatonun tasdike ilişkin kararın kesinleşmesiyle birlikte bağlayıcı olacağının, tasdik edilen konkordato projesinde kararlaştırılması da mümkündür. İşte bu durumda, mühletin etkileri, mühletin sonuçları hakkında saydığımız istisnalar saklı olmak üzere, konkordatonun bağlayıcılık kazandığı zamana kadar sürecektir. Bu durumda, mühletin etkilerinin 29 ay ile sınırlı olacağı kuralı da esnetilmiş olacaktır (Arslan vd. 2020: 583).

\subsection{3. İmtiyazlı Alacaklar Bakımından}

İcra ve İflas Kanunu'nun 206. maddesinin birinci sırasında yazılı imtiyazlı alacaklar için haciz yoluyla takip yapılabilir veya daha önceden başlanmış olan takipler, devam ettirilebilir

\footnotetext{
${ }^{15}$ Aynı yönde bkz.: Yargıtay 12. HD., T.18.3.2021, E.2020/7768, K.2021/3179 sayılı kararı.

${ }^{16}$ (https://lib.kazanci.com.tr/kho3/ibb/files/is-istanbulbam-17hd-2020-2121.htm)
} 
(İ̈K m.294, II; Tanrıver, 1993: 67). Burada, ilgili sürelerin, konkordato mühletinin verilmesinden itibaren değerlendirilmeye tabi tutulması gerekir (Tanrıver, 1993: 67, dn.26).

\subsubsection{Takas Hakkı Bakımından}

Takas, İcra ve İflas Kanunu'nun 200 ve 201. maddeleri hükümleri uyarınca değerlendirilir. Fakat, takas hükümlerinin hangi andan itibaren işleyeceği konusunda eskiden mevcut olan belirsizlik giderilmiş ve yukarıda işaret edilmiş olan maddelerin uygulanmasında, geçici mühletin ilânı tarihinin esas alınacağına vurgu yapılmıştır (İ̈K m.294, IV; Yılmaz, 2016: 1266; Pekcanıtez vd., 2019: 469; Simil, 2020: 199-200). Takas hakkını kimin kullanacağı noktasında, kural, alacaklının takas beyanında bulunmasıdır. Ancak, doktrinde de ifade edildiği gibi, hem alacaklıların hem de borçlunun lehine olacaksa, borçlunun da takas beyanında bulunabilmesi kabul edilmelidir (Atalı vd. 2020: 661).

İstanbul Bölge Adliye Mahkemesi 17. Hukuk Dairesi de, 30.1.2020 günlü ve E.2019/2035, K.2020/245 sayılı kararında, konkordato mühleti içerisinde takasın gerçekleşebilmesi için her iki alacağın da mühlet kararının ilanından önce doğduğuna isabetli bir şekilde hükmetmiştir ${ }^{17}$. Kararda, "....alacaklıların takas haklarının sınırlandırıldığı ve ancak iflasta takası düzenleyen hükümler gereğince takasin gerçekleştirilebileceğine ve İ̈K 287. maddedeki mahkemenin borçlunun malvarlığının muhafazası için gerekli gördüğ̈̈ bütün tedbirleri alır düzenlemesi de göz önünde bulundurularak, konkordatonun amacı ile aykırı düşmeyecek olan, borçlu şirketin kendi hesaplarnna, geçici mühletin ilan tarihi ve sonrasında gelen para üzerine bloke konulmamasına ve konulmuşsa kaldırlması ile mahsup işleminin iptaline yönelik ihtiyati tedbir kararı verilmesine dair..." hüküm kurulmuştur.

\subsubsection{Hacze ve Davalara Etkisi Bakımından}

İcra ve İflas Kanunu'nun 294. maddesinin beşinci fıkrasına göre ise, hacizli mallar hakkında niteliğine uygun düştüğü ölçüde İcra ve İflas Kanunu'nun 186. maddesi hükmü uygulanacaktır. Buna göre, hacizli mallar satılamaz, ancak satış yapılmışsa elde edilen gelir, hacze katılan ve alacağını sıra cetveline yazdıran alacaklılar arasında paylaştırılır. Bu paylaşım sonucunda artan kısım, borçlunun malvarlığına dahil edilecektir (Atalı vd. 2020: 662). Buradan çıkarılması gereken sonuç, konkordato mühletinin, daha önce konulmuş hacizleri ortadan kaldırmayacağı, yani daha önce başlatılan takiplerin olduğu yerde duracağı, düşmenin söz konusu olmayacağı ve bu sebeple de mühlet kararının devamı süresince alacaklının haciz hakkının saklı kalacağıdır (Tunç Yücel, 2020: 136). Hacizlerin düşmesine sebep olan şey, konkordatonun tasdiki veya mühletin kaldırılması kararıdır.

Geçici mühlet kararından önce başlatılmış olan bir takip, geçici mühlet kararıyla birlikte duracaktır. Mühlet kararı sonrasında, borçlunun menkul ya da gayrimenkulleri üzerine haciz konulamaz ${ }^{18}$.

Haciz bakımından ise, konkordatonun sonuçlanmayan takiplere etkisi, Kanun'un 308/ç maddesinde gösterilmiştir. Maddenin birinci fıkrasına göre, geçici mühlete ilişkin kararın verilmesinden önce başlatılıp, haciz konulmuş fakat paraya çevrilmemiş takipler, konkordato mühletinin bir sonucu olarak düşer (Arslan vd. 2020: 583). Ancak, bu hüküm,

\footnotetext{
17 (https://ib.kazanci.com.tr/kho3/ibb/files/is-istanbulbam-17hd-2019-2035.htm)

18 Yargitay 12. HD., T.20.5.2021, E.2020/8667, K.2021/5103. (https://lib.kazanci.com.tr/kho3/ibb/files/12hd-20208667.htm)
} 
yukarıda bahsetmiş olduğumuz imtiyazlı alacaklar, rehinli alacakların rehin tutarı karşılığı ve 6183 sayılı Kanun kapsamındaki kamu alacaklarını etkilemez (Arslan vd. 2020: 583). Yani İcra ve İflas Kanunu'nun 308/c maddesinin üçüncü fıkrasındaki alacaklar hakkında başlatılmış takiplerde, haciz konulmuş ve paraya çevirme işlemi gerçekleşmemiş olsa bile, takibin düşmesinden bahsedilemez.

İhtiyati hacze ilişkin olarak, İstanbul Bölge Adliye Mahkemesi 14. Ceza Dairesi'nin, 31.1.2019 günlü ve E. 2019/150, K.2019/129 say1lı kararıyla19, “...Asıl borçlu şirket hakkında konkordato geçici veya kesin mühletinin verilmesi, ihtiyati haciz kararı verilmesine engel değildir. Yasa hükmü, ihtiyati haciz kararının verilmesini değil, uygulanmasın engellemektedir. Bu nedenle, ilk derece mahkemesince itiraz eden borçlu şirketin ihtiyati hacze vaki itirazının reddi..." yönünde hüküm kurulmuştur.

Konkordato mühletinin davalara etkisi bağlamında bir değerlendirme yapılacak olursa; konkordato mühleti içerisinde, borçluya karşı yeni davaların açılabilmesinin ve açılmış davalara devam edilmesinin önünde herhangi bir engel bulunmadığını da belirtmek gerekir (Tanrıver, 1993: 68; Kuru, 2016: 688; İflas davalarının mühlet içinde açılamayacağı, açılmış ise duracağı konusunda bkz.: Akil, 2019a: 239-240).

Tasarrufun iptali davaları bağlamında ise, ister komiserin denetiminde olsun isterse de mahkemenin izniyle yapılmış olsun, konkordato mühleti içerisinde borçlunun yapacağı işlemler sebebiyle tasarrufun iptali davasının açılmasının mümkün olduğu görüşüne katılmaktayız (Şahin, 2020: 237-239).

\subsubsection{Alacağın Devri Sözleşmeleri Bakımından}

Konkordato mühletine karar verilmesinden önce, müstakbel bir alacağın devri sözleşmesi yapılmış ve devredilen alacak konkordato mühletinin verilmesinden sonra doğmuşsa, bu devir hükümsüz olacaktır (İ̈K m.294, VI). Yani, konkordato mühletinin verilmesinden önce doğup devredilmiş bir alacak, mühletten sonra muaccel olmuşsa, devir işlemi geçerliliğini koruyacağından (Pekcanıtez ve Erdönmez, 2018: 128), ödemenin temlik alana yapılması gerekir (Atalı vd. 2020: 663). Madde gerekçesinde, bu hükmün amacının, borçlunun konkordato alacaklılarının müracaat edebileceği malvarlığını korumak olduğuna işaret edilmiştir. Ancak, Yargitay, konkordato mühleti verilmesinden önceki işlemlerin geçerliliğini sürdüreceğine ve mühlet verilmesinden önce vezneye giren paranın alacaklısına ödeneceğine işaret etmiştir ${ }^{20}$.

\subsubsection{Konusu Para Olmayan Alacaklar Bakımından}

Konusu para olmayan alacaklar, alacaklı tarafından ${ }^{21}$, ona eşit değerde bir para alacağına çevrilerek komisere bildirilir. Ancak, önemle altı çizilmelidir ki, mehaz Kanun'un 297. maddesinin dokuzuncu bendinden aynen alınan kurala göre, borçlunun, taahhüdünü aynen

\footnotetext{
19 (https://lib.kazanci.com.tr/kho3/ibb/files/is-istanbulbam-14hd-2019-150.htm)

${ }^{20}$ Yılmaz, 2016: 1265'de yer alan Yargıtay 12. HD.'nin 18.6.2012 günlü ve 12184 E., 13107 K. sayılı kararı.

${ }^{21}$ Konusu para olmayan alacakların alacaklı tarafından değil de, konkordato komiseri tarafından paraya çevrilmesi şeklinde bir düzenleme getirilmesinin daha uygun olacağı yönündeki görüş için bkz.: (Akil, 2019a: 251). Yine, özellikle kötüniyetli bir şekilde alacakların şişirilebileceği ya da hileli paraya çevirme işlemleri yapılabileceğinden, şişirilmiş alacakların da önüne geçilmesi maksadıyla paraya çevirme işleminin komiser tarafından yapılması gerektiği yönünde bkz.: (Pekcanıtez ve Erdönmez, 2018: 129).
} 
ifa etmesini üstlenmesine komiserin onayının bulunması şartıyla herhangi bir engel bulunmamaktadır (İ̈K m.294, VII). Eskiden de, doktrinde, konkordato mühleti verilmesiyle birlikte alacaklıların, konusu paradan başka bir şey olan alacaklarının, para alacağına dönüşeceği, komisere, alacakların para alacağ1 olarak kaydettirilmesi gerektiği ifade edilmekteydi (Tanrıver, 1993: 83). Yine, bahsi geçen alacakların muaccel olması da şarttır (Tunç Yücel, 2020: 204). Ayrica, borcu aynen ifa edecek olan kişi borçludur ve konusu para olmayan alacaklar paraya çevrilirken, alacağın geçici mühletin verildiği tarihteki değerinin esas alınması gerekmektedir (Tunç Yücel, 2020: 205).

\subsubsection{Faiz İşlemesi Bakımından}

Tasdik edilmiş olan konkordato projesinde aksine bir hüküm bulunmuyorsa, kesin mühletin verildiği tarihten başlayarak rehin ile temin edilmemiş her türlü alacağa faiz işlemesi duracaktır (İ̈K m.294, III; Balc1, 2007: 148; Coşkun, 2016: 4870). Yani, konkordato mühleti verilmesi halinde, borçlu ve alacaklıların anlaşması halinde, faizler işlemeye devam edebilir (Akil, 2019a: 245). Doktrinde, komiserin onayı ile doğmuş borçların ve konkordato kapsamında değerlendirilmeyen imtiyazlı alacakların takip konusu edilmesi halinde, mühlet süresi için faiz istenebileceği ifade edilmiştir (Uyar, 2019: 165).

Yargitay'ın, 16.2.2021 günlü ve E. 2021/1389, K.2021/275 sayılı kararında, geçici mühlet, kesin mühletin sonuçlarını doğuracağından, geçici mühlet tarihinden itibaren, adi alacaklara faiz işletilmesi duracağı ve asıl alacaklının alacağının 294. maddenin üçüncü fıkrasına göre, mühlet sonrası faiz işletilmeden belirlenmesi, kefilin henüz ödemediği borç için nisaba dahil edilmesinin önüne geçilmesi ve nisabın yeni oluşacak alacak miktarı ve alacaklı sayısına göre belirlenmesi gerektiği ifade edilmiştir ${ }^{22}$.

\subsubsection{Rehinli Alacaklılar Bakımından (İIK m.295)}

İcra ve İflas Kanunu'nun 295. maddesinin birinci fıkrasına göre, mühletin alacaklılar bakımından sonuçlarından bir diğeri, rehinle temin edilmiş olan alacaklar için rehnin paraya çevrilmesi yoluyla takibe başvurulabilmesi, daha önceden başlatılmış olan takiplerin devam ettirilebilmesidir. Ancak, daha önceden başlamış ya da yeni başlatılacak takiplerde, borçlunun herhangi bir teminat göstermesine gerek olmaksızın, rehin konusu mallar satılamayacağı gibi, haklarında muhafaza tedbirine de hükmedilemez (Pekcanıtez ve Erdönmez, 2018: 118-119). İcra ve İflas Kanunu'nun 290. maddesine göre alacaklılar kurulunda yer alması öngörülen rehinli alacaklılar da, 295. maddenin gerekçesinde de ifade edildiği üzere, konkordato teklifinde bulunabileceklerdir.

Doktrinde, ticari faaliyetin devam etmesi için gerekliyse ve diğer alacaklıların da yararına olmak kaydıyla konkordato komiserinin, rehin alacaklısının alacağının mühlet içerisinde ödenmesine karar verebilmesi gerektiği ifade edilmekteydi (Tunç Yücel, 2020: 230). İcra ve İflas Kanunu'nun 295. maddesine 9.6.2021 günlü ve 7327 sayılı Kanun ile eklenen ikinci fıkra uyarınca, konkordato projesinde, işletmenin faaliyetleri için kullanılacağı belirtilmemiş ya da değerini kaybedebilecek veya muhafazası masraflı olacak rehinli malların, satılması mümkün olacaktır (İ̈K m.295, II). Bu satışa ilişkin karar verecek olan merci mahkemedir. Mahkemenin bu izni verebilmesi için, komiserin görüşünü ve alacaklılar kurulunun onayını alması zorunlu tutulmuştur (İ̈K m.297, II).

${ }^{22}$ (https://lib.kazanci.com.tr/kho3/ibb/files/15hd-2021-1389.htm) 
Rehnedilmiş olan malın, borçluya ait olmaması halinde dahi, rehinli alacaklı, konkordato mühleti içerisinde, borçluya karşı rehnin paraya çevrilmesi yoluyla takip başlatabilecek ve önceden başlamış takipleri devam ettirebilecektir (Tanrıver, 1993: 66).

Konkordato talebinden önce ya da konkordato komiserinden izin alınmadan, mühlet içerisinde doğmuş tüm alacaklar, konkordatonun bağlayıcı hale geldiği andan itibaren konkordato projesine tabidir (Pekcanitez ve Erdönmez, 2018: 119; İIK m.308/c, II)23. Ancak, 206. madde kapsamindaki ilk sırada yer alan imtiyazlı alacaklar, rehinli alacaklıların rehin bedelini karşılayan kısmındaki alacakları ve 6183 s. Kanun kapsamındaki kamu alacakları, konkordato talebinden önce ya da konkordato komiserinden izin alınmadan mühlet içerisinde doğsa bile konkordato projesi bunlar için bağlayıcı olmaz (İ̈K m.308/c, III; Atalı vd.2020: 687-688).

İcra ve İflas Kanunu'nun 308/c maddesinin dördüncü fıkrasına göre, geçici mühlet kararı verildikten sonra konkordato komiserinin izniyle akdedilen borçlar, temerrüt şartları oluşmuşsa, icra takibine konu edilebilirler ve 206. maddede yer alan rehinli alacaklar hariç olmak üzere, tüm alacaklardan önce ödenir ve konkordato şartlarına tabi olmazlar (Pekcanitez ve Erdönmez, 2018: 119). Bu borçlara, kredi kurumlarınca verilmiş olan krediler de dahildir.

Son olarak ifade edilmelidir $\mathrm{ki}$, rehinli alacaklar, takip yapılması bağlamında, kamu alacaklarına nazaran önceliklidir. Rehinli alacaklara böyle bir imkanın tanınmasının sebebi, konkordatonun ayni hakları etkileyen bir kurum olmamasıdır (Duran, 2019: 147). Yine, alacağı rehinle karşılanmış alacaklılar, konkordato projesinden etkilenmeyeceği için, konkordatonun tasdikine itiraz etmeleri halinde, bu başvuru, hukuki yarar yokluğu sebebiyle usulden reddedilir ${ }^{24}$.

\subsection{Mühletin Sözleşmeler Bakımından Sonuçları (İIK m.296)}

\subsubsection{Genel Olarak}

Genel olarak, ifa, fesih, dönme, geri alma ve iptal sözleşme ilişkisini sona erdiren sebepler arasında sayılmaktadır (Eren, 2014: 1257). Bu örnekler arasında saymadığımız ölüm, fiil ehliyetinin kaybı, iflas veya süreli sözleşmelerde sürenin sona ermesi diğer sözleşme ilişkisini sona erdiren istisnai durumlar arasındadır (Eren, 2014: 1257-1258).

\subsubsection{Sözleşmelerin Ayakta Tutulması Bakımından}

Konkordato mühleti sırasında, borçlunun, işletmesinin faaliyetlerini devam ettirmesi esas olduğundan, taraf olarak yer aldığı sözleşmelerin de ayakta tutulması gerekir. Bu sebeple, İcra ve İflas Kanunu'nun 296. maddesi ile bu sözleşmenin diğer tarafının konkordato projesinden etkilenecek olmasına bakılmaksızın, sözleşmelerin devam edeceğine işaret edilmiştir. Bu bağlamda, sözleşmede, borçlunun konkordato prosedürüne işlerlik kazandırmasının, haklı feshi sebebi sayılacağı, borcu muaccel hale getireceğ

23 “...̇̇cra ve İflas Kanunu'nun 308/c maddesinin ikinci fikrasına göre, projede yer alsın veya yer almasın anılan borçlar için konkordato hükümleri geçerli olacaktır. Bu nedenlerle hükme tablo eklenmesi ve tablo dışındaki alacaklıların alacaklarının yok sayılması anılan yasal düzenlemeye uygun değildir..." Ankara Bölge Adliye Mahkemesi 23. HD., T.2.6.2021, E.2021/222, K.2021/840. (https://lib.kazanci.com.tr/kho3/ibb/files/is-ankarabam-23hd-2021-222.htm)

24 Ankara Bölge Adliye Mahkemesi, 23. HD., T.4.11.2020, E.2020/1403, K.2020/1401. (https://lib.kazanci.com.tr/kho3/ibb/files/is-ankarabam-23hd-2020-1403.htm) 
sözleşmeye aykırılık teşkil edeceğine yönelik hükümlere, sırf borçlunun konkordatoya başvurmuş olması sebebiyle işlerlik kazandırılması mümkün değildir. Ancak, bu yöndeki hükümlerin sözleşmeye eklenmesi iradi olup, yasal bir düzenlemeden kaynaklanmiyorlarsa etkisiz sayılırlar. Yani, bu kayıtlar yasal bir gereklilik üzerine sözleşmeye konulmuş yahut yasanın emredici hükümlerindense, konkordato mühleti verilse bile, sözleşmenin feshine ilişkin yasa hükümleri uygulanabilir (Atalı vd. 2020: 667).

Sözleşmedeki hükümlerden bağımsız olarak, borçlunun taraf olduğu ve işletmenin devamını sağlayacak sözleşmeler sona erdirilemez. Ancak, bu hükümlerin varlığı, geçici ve kesin mühlet sırasında, tarafların edimlerini karşılıklı olarak ifa etmesini engellemez, aksine devam eden sözleşmeler sebebiyle borçlanılan edimler ifa edilecektir (İ̈K m.296, I, c.son). Bu doğrultuda, 7327 sayılı Kanun ile değiştirilen İcra ve İflas Kanunu'nun 308/c maddesinin dördüncü fıkrasına göre, geçici mühlet kararı verildikten sonra konkordato komiserinin izniyle akdedilen borçlar, temerrüt şartları oluşmuşsa, icra takibine konu edilebilirler ve 206. maddede yer alan rehinli alacaklar hariç olmak üzere, tüm alacaklardan önce ödenir ve konkordato şartlarına tabi olmazlar. Bu borçlara, kredi kurumlarınca verilmiş olan krediler ve karşı edimin ifasının komiserin izniyle borçlu tarafından kabul edildiği sürekli borç ilişkilerindeki karşı edimler de dahildir.

Burada ifade edilmesi gereken bir başka husus, konkordato mühleti verilmesi ile borçlunun müeccel borçlarının, muaccel hale gelmeyeceği ve borçların vadesinden önce talep edilebilmesine tek başına gerekçe gösterilemeyeceğidir (Tanrıver, 1993: 82). Yine, bu sözleşmelerin kanundan dolayı derhal sona erdiği söylenemez (Akil, 2019b: 225). Ayrıca, bahsi geçen sözleşme hükümlerinin uygulanmaması için sözleşmenin karşı tarafının konkordato projesinden etkilenip etkilenmediğine bakılmayacak ve böylece, borçluya temel mal veya hizmet sağlayan sözleşmelerin devam etmesi amaçlanmaktadır.

\subsubsection{Sözleșmelerin Feshedilmesine İlişkin Hükümler}

Borçlu, taraf olarak yer aldığı konkordatonun amacına ulaşmasını engelleyen (Simil, 2020: 177) "aşırı külfetli" sürekli borç ilişkilerini (Akil, 2019: 226), fesihten önce veya fesih anında (Akil, 2019b: 232) komiserin uygun görüşü ve mahkemenin izniyle herhangi bir zaman sonlanacak şekilde feshedebilir (İ̈K m.296, II, c.1; Simil, 2020, 175-176).

Günümüzde hala etkisini göstermekte olan Covid-19 salgını döneminde de, sürekli borç ilişkilerinin, borçlular bakımından önemli bir külfet yaratmış olması, ihtimal dahilindedir (Ermenek ve Kartal, 2020: 498). Bu duruma, yaşanan ekonomik sıkıntının, iş alanını daralttığına ve kiralanarak kullanılan iş aletlerinin önemli bir kısmına ihtiyaç kalmaması örnek olarak gösterilmiştir. Covid-19 salgını tüm borç ilişkilerini etkilemese de, özellikle eğitim, inşaat, ulaşım, konaklama ve turizm sektörlerinde önemli sıkıntılar doğmuştur (Ermenek ve Kartal, 2020: 498-499). Doktrinde, Covid-19 sebebiyle, 1.03.2020 ile 30.06.2020 arasını kapsayacak şekilde 7226 sayılı Kanun'un ikinci maddesiyle getirilen kira sözleşmelerine dayanan fesih ve tahliyelerin engellenmesi hususunun İcra ve İflas Kanunu'nun 296. maddesinin ikinci fikrasiyla birlikte değerlendirilmesi sonucunda, burada bir olağanüstü fesih hali bulunması sebebiyle bu geçici düzenlemeden etkilenmeyeceği ifade edilmiştir (Ermenek ve Kartal, 2020: 505-506). Aynı yazarlar, sözleşmenin uyarlanması imkanı mevcutsa, fesih yerine bu imkanın kullanılması gerektiğinden bahisle İcra ve İflas 
Kanunu'nun 296. maddesine yapılacak bir eklemeyle borçluya, uyarlama talep etme imkanı tanıyan bir hükmün eklenmesi önerilmektedir (Ermenek ve Kartal, 2020: 510-511).

$\mathrm{Bu}$ hükümle amaçlanan, işletme veya müessese üzerinde aşırı külfet yaratan, verimli olmayan bir takım eski sözleşmelerin (örneği; kira, finansal kiralama, lisans) devamının engellenmesi ve konkordatonun başarıya ulaşması amacıyla gerekirse tazminat ödenmek suretiyle sona erdirilmesidir. Doktrinde de ifade edildiği üzere, borçluya tanınmış olan bu yetki kullanılırken, komiserin de izni alınmalı ve kötüye kullanımların önüne geçilmelidir (Pekcanitez ve Erdönmez, 2018: 130-131; Sarısözen, 2021: 398). Örneğin, konkordatonun sadece tasfiye amacı taşıdığı, tasfiyeyle birlikte iyileşme amacı taşımadığı durumlarda, borçlunun sürekli borç ilişkilerinden kurtarılması anlamsız olabilir (Ermenek ve Kartal, 2020: 497).

Buradaki fesih, olağanüstü fesih olarak kabul görmektedir (Sarıözen, 2021: 396). Bu çerçevede ödenmesi gereken tazminat, yani karşı tarafın sözleşmenin sona ermesinden dolayı uğradığı zarar, borçludan, konkordato alacağı olarak talep edilebileceğinden (Akil, 2019b: 232), konkordato projesine dahil olur (İ̈K m.296, II, c.2). Dolayısıyla, taşıdığı önem de göz önünde bulundurulduğunda, bu imkanın kullanılması, komiserin onayına ve sonrasında mahkemenin iznine bağlıdır (Türkoğlu, 2019: 146).

Şayet, sürekli borç ilişkisi feshedilmez ve ilişki devam ederse, borçlunun, sözleşmeden kaynaklı tüm edimlerini konkordato koşullarından bağımsız bir biçimde gerçekleştirmesi gerekir (Akil, 2019b: 231).

\subsubsection{Hizmet Sözleşmeleri Bakımından}

Hizmet sözleşmeleriyle ilgili olarak, istisnai bir düzenleme getirilmiştir. Hizmet sözleşmeleri, diğer sürekli borç ilişkisi doğuran sözleşmeler gibi feshedilemeyeceğinden, yukarıda anlatılan usulde fesih mümkün değildir. Çünkü bu sözleşmeler, yerinde bir düzenlemeyle (Akil, 2019b: 229) ekonomik açıdan zayıf konumda bulunan kişilerin korunması adına diğer sözleşmelere ilişkin hükümlerden ayrık tutulmuştur (İ̈K m.296, II, c.3).

Hukukumuzda, feshe ilişkin olarak; belirsiz süreli yapılmış olan hizmet sözleşmelerinin ancak, olağan fesih ya da olağanüstü fesih halinde sona ereceği düzenlenmiştir (TBK m. 432). $\mathrm{Bu}$ duruma ilişkin Kanun'un emredici hükümleri, belirsiz süreli hizmet sözleşmesinin deneme süresi içerisinde sona ermesi bağlamında Türk Borçlar Kanunu'nun 433. maddesinde yer almaktadır. Belirli süreli hizmet sözleşmelerinin sona ermesi bağlamında, kural olan sözleşmesel ilişkinin belirlenmiş olan sürenin sonuna kadar devam ettirilmesidir ve bu nedenle haklı nedenle derhal fesih geçerli olacaktır.

Türk Borçlar Kanunu'nun 434. maddesinde, feshe ilişkin olarak, işçinin, fesih hakkının işveren tarafından kötüye kullanılması ihtimalini göz önünde bulundurularak, hizmet sözleşmesini fesih hakkını kötüye kullanarak sona erdiren işverenin, iş̧̧iye belirli bir miktar tazminat ödeyeceğine ilişkin emredici düzenleme getirilmiştir (Eren, 2014: 566-567).

\subsection{Mühletin Borçlu Bakımından Sonuçları (İIK m.297)}

\subsubsection{Genel Olarak}

Konkordato sürecinin amaçlanan şekilde sonuçlandırılabilmesi için, taraflar arasındaki dengenin bozulmaması ve haklarının korunması gerektiğini yukarıda ifade etmiştik. 
Dolayısıyla, borçlunun malvarlığının korunması ve alacaklıların menfaatlerinin de gözetilmesi gerektiğinden, borçlunun malvarlığında meydana gelebilecek azalmalara ya da işletmesinin faaliyetlerini güçleştirecek kararlar alınmasına engel olunması gerekmektedir (Türkoğlu, 2019: 102; Simil, 2020: 91 vd.). Buna rağmen, iflas prosedürünün aksine, konkordato mühleti içinde, borçlunun tasarruf yetkisinin tümden kısıtlandığını söylemek yanlış olacaktır (Pekcanitez ve Erdönmez, 2018: 126). Kural olarak borçlu tasarruf yetkisine sahiptir ve ticari hayatını devam ettirebilir (Arslan vd., 2020: 546; Pekcanitez vd., 2019: 470471; Ercan, 2009: 218). Nitekim, konkordato sürecine işlerlik kazandırılmasındaki en önemli motivasyon, alacaklılar ve borçlu arasındaki dengenin korunarak ticari ilişkilerin devamının sağlanmasıdır (Aslanoğlu ve Cengiz, 2021: 42). Bu itibarla borçlunun ticari faaliyetlerini devam ettirmesi son derece elzemdir. Dolayisiyla da konkordato mühletinin (geçici mühletin) verildiği andan itibaren borçlunun malvarlığı üzerindeki tasarruf yetkisi mahkemece sınırlandırılabilir (Simil, 2020: 108; Sarısözen, 2021: 407-408).

Yargıtay ve bölge adliye mahkemesi kararlarına da konu olduğu üzere, konkordato mühleti verilmesinden sonra, tasdik sürecinde, 5941 sayılı Çek Kanunu'nun 5. maddesi uyarınca, karşılıksız çek sebebiyle açılan ceza davalarında, konkordato sürecinin yürütüldüğ̈̈ asliye ticaret mahkemesinden, sürecin akıbeti hakkında bilgi alınması için bekletici mesele yapılmasına yönelik hüküm kurulmaktadır. Buna göre, suç konusu olan çekin, konkordato projesine tabi olup olmadığı, bankaya ibraz edildiği tarihte, devam eden bir konkordato süreci olup olmadığı ve bilhassa tüzel kişi adına keşide edilmiş çek üzerine karşılıksızdır işlemi yapılmışsa ne tür karar verileceği hususları üzerinde durulmaktadır.

Bursa Bölge Adliye Mahkemesi 5. Ceza Dairesi'nce verilen 19.6.2020 günlü ve E.2019/1772, K.2020/1499 sayılı karar uyarınca suça konu çekin bankaya ibraz tarihi dikkate alınarak ve konkordato sürecinin yürütüldüğ̈̈ mahkemeye sorularak, dosyası istenip incelenerek, belirtilen sürecin sonucunun bekletici mesele yapılıp yapılmayacağl, ceza sorumluluğun bulunup bulunmadiğına ilişkin aşamalar da değerlendirilerek ve dava konusu çekin konkordato projesine dahil olup olmadığı da belirlendikten sonra sanık hakkında karar verilebileceği yönünde hüküm kurulmuştur ${ }^{25}$.

Yine, Yargitay 19. Ceza Dairesi'nin 10.6 .2109 günlü ve E.2019/23974, K.2019/9339 sayılı ilamında özetle “...Konkordatonun tasdiki kararıyla birlikte kesinleşen konkordato anlaşmasına göre hüküm ve sonuçlar yeniden belirlenen suça konu çekin, ibraz tarihinden sonra suçun konusunu oluşturan zorunlu unsurları sahip bir çek olmaktan çıkması, dolayısıyla tüzel kişi yetkilisi olan sanıkların cezai sorumluluğundan söz edilemeyeceği, şayet çek hesabı tüzel kişi hakkında konkordatonun herhangi bir nedenle reddine karar verilirse; bu sefer bekletici sorun kararmmn kaldırılmasıyla ceza yargılamasına devam edilerek İcra ve İlas Kanunu'nun 297. maddesine göre, konkordato komiseri atanmasıyla birlikte tüzel kişinin yetkili temsilcilerinin şirketi yönetim ve temsil yetkisinin kendiliğinden ortadan kalkmayacağı, bununla beraber mahkemenin hangi işlerin şirket yöneticileri tarafindan hangi işlerin komiser tarafindan yapılacă̆ına dair karar verme yetkisinin bulunduğu gözetilerek, mahkemece, konkordatonun reddi kararına kadarki süreçte, şayet çek hesabını yönetimi, bu hesaba para aktarma, çek hesabı üzerinde tasarruf etme gibi yetkilerin şirket yönetim organından alını komisere verilmesi yönünde bir karar verilmişse ve bankaya ibraz edilen çek, komiserin yetkili olduğu dönemde karşıllısız çıkmışsa; bu durumda şirket yetkilisi gerçek kişilerin

25 (https://lib.kazanci.com.tr/kho3/ibb/files/is-bursabam-5cd-2019-1772.htm) 
5941 Sayılı Çek Kanunu'nun 5. maddesi gereği cezai sorumluluklarının devam etmeyeceğine, tasdike karar verecek mahkemece, konkordatonun reddi kararına kadarki süreçte, şayet çek hesabın yönetimi, bu hesaba para aktarma, çek hesabı üzerinde tasarruf etme gibi yetkilerin şirket yönetim organından alınıp komisere verilmesi yönünde açık bir karar verilmemişse; bu konudaki tüm yetkiler şirket yöneticilerinde olacağından, söz konusu kişilerin bu süreçte bankaya ibraz edilen ve karşılıksız çıkan çekten dolayı 5941 Sayılı Çek Kanunu'nun 5. maddesi gereği cezai sorumluluklarının devam edeceğine..." karar verilmiştir ${ }^{26}$.

Adına çek keşide edilmiş tüzel kişi adına başlatılmış bir konkordato süreci yoksa ve çek üzerinde "karşılıksızdır işlemi yapılmasına sebebiyet verme" suçu işlenmişse, suçun işlenmesinden sonra yapılacak konkordato talebinin, İcra Ceza Mahkemesinde açılan ve görülmeye devam edilen ceza davasında "bekletici sorun" yapılması için maddi veya hukuki bir sebep bulunmadığından bahisle açılan ceza yargılamasına devam edilmesi ve şartları mevcutsa mahkumiyet hükmü verilmesi gerektiği yönünde hüküm kurulmuştur (Yargitay 19. CD. T.15.6.2020, E.2020/2053, K.2020/6650).

\subsubsection{Borçlunun Tasarruf Yetkisi Bakımından}

Borçlunun tasarruf yetkisinin kısıtlanması söz konusu olduğunda konkordato komiseri devreye girer. Çünkü borçlu, kural olarak komiserin işlerini yürütür. Bazı işlemlere özgü olarak, borçlunun konkordato komiserinden izin alması ya da komiserin, borçlu yerine geçerek işletmenin faaliyetlerini devam ettirmesi kararını alma yetkisi, mahkemeye verilmiştir (Simil, 2020: 113 vd.). Mahkemenin kararı, İcra ve İflas Kanunu'nun 288. maddesi uyarınca ilan edilir, ilgili yerlere de bildirimde bulunulur (İ̈K m.297, IV). Bu karar, mühlete hükmederken alınabileceği gibi, mühlet süresi içerisinde de alınabilir (İ̈K m.297, I; Pekcanitez vd., 2019: 470).

Borçlunun, mühlet kararının verilmesinden sonra, mahkemenin izni olmaksızın rehin tesis etmesi, kefil olması, ivazsız tasarruflarda ${ }^{27}$ bulunması mümkün değildir. Yine, borçlunun, işletmesinin faaliyetinde önemli bir konumda bulunan taşınırı ve devamlı tesisatıyla taşınmazını devretmesi ${ }^{28}$ ve takyit etmesi yasaklanmıştır. Bu kısıtlamalara uyulmamasının yaptırımı, yapılan işlemlerin hükümsüz (Atalı, 2018: 96; Simil, 2020: 134) sayılmasıdır29. Nitekim, burada sayılan hususlar, sınırlı sayma ilkesine tabi olup genişletilmeleri mümkün değildir (Kuru, 2016: 689; Tanrıver- Mühletin Kaldırılması, 2005: s.319; Sarısözen, 2021: 187). Ancak, örneğin, işletmenin faaliyetlerinin devamı için önemli olmayan taşınırların satılması, diğer taşınır veya taşınmazların kiraya verilmesinin önünde bir engel bulunmamaktadır (Türkoğlu, 2019, 102). Borçlunun yukarıdaki işlemleri kesin bir biçimde yapamayacağı ve mutlak butlan yaptırımına tabi kılınmış işlemlerin, mahkemenin iznine bağlanması olumlu

\footnotetext{
${ }^{26}$ (https://lib.kazanci.com.tr/kho3/ibb/files/19cd-2019-23974.htm) Benzer yönde bir karar için bkz.: Erzurum Bölge Adliye Mahkemesi 5. CD., T.27.11.2019, E.2019/4575, K.2019/2426.

${ }_{27} \mathrm{Bu}$ kavramdan ne anlaşılması gerektiği noktasında, Tanrıver, borçlunun münferit malvarlığı değerlerini, başkalarına kazandırmak amacıyla yaptığı bağışlamaların anlaşıldığını, bunun yanında borçlunun, başkalarının lehine, sadece kendi malvarlığının durumunu ağırlaştıran ya da yeni yükler getiren işlemler ile sorumluluk üstlenilmesinin de dahil olduğuna işaret etmektedir (Tanrıver, 1993: 74).

${ }_{28} \mathrm{Bu}$ ibarenin, 4949 sayılı Kanun'dan önce, gayrimenkullerin satılması ibaresinin yer alması nedeniyle uygulamada çıan tereddütlerin önlenmesi amacıyla getirildiği hakkında bkz.: (Tanrıver- 4949 sayılı Kanun, 2005: 358). (Ayrica bkz. Yilmaz, 2014: 731).

${ }^{29}$ İsviçre doktrininden ifade edilen bir görüşe göre, başlangıçta hakimin izninin alınmadan işlem yapılmış olması, mühletin sonuna kadar izin alınması şartıyla işlemlerin geçersizliği sonucunu doğurmamalıdır (Ercan, 2009: 224).
} 
bir hamle olmakla birlikte, mahkemenin bu konuda katı bir tutum sergilemesi de doğru olmayacaktır. Yine de, mahkeme, bu işlemler hakkında karar vermeden önce komiserin görüşünü ve alacaklılar kurulunun muvafakatini almakla ödevli kılınmıştır (İ̈K m.297, II, c.son).

Dikkat çekilmesi gereken bir diğer husus ise, konkordato mühletine ilişkin mahkemece verilen kararın içeriğinin de son derece önem arz ediyor olmasıdır. Nitekim, uygulamada, verilen mühlet kararları kimi zaman oldukça detaylı olabilirken, kimi zaman da kalıplaşmış ve genel ifadelerin kullanıldığı metinler olarak karşımıza çıkmaktadır. Dolayısıyla mahkemece verilen mühlet kararının, borçlunun tasarruf yetkisinin kısıtlanmasına ilişkin hükümleri net değilse veya eksikse, ilgili mercilerde işlem yapılması oldukça güç olabilir. Uygulamada, mahkeme tarafından, İcra ve İflas Kanunu'nun 297. maddesinin birinci fıkrası uyarınca, borçlunun tasarruf yetkisi belirli ölçüde kısıtlanmışsa, kişinin noterde işlem yaptığı sırada bu mahkeme kararını sunması istenmektedir. Yine, hangi yetkilerin kısıtlandığı açık değilse, konkordato komiserinin borçluya nezaret etmekle yükümlü kılınması sebebiyle (İ̈K m.290, b; m.289, III; m.297, I), komiserin o işleme onay vermesi gerekebilir. Somut bir örnek vermek gerekirse, bir araç alım satımı yapmak isteyen borçlunun, noterde işlem yapmak istediği sırada, aracın, 297. maddenin ikinci fıkrasında kendisine yer verilen "işletmenin faaliyetinin devamı için önem arz eden" taşınır olmadığını kanıtlaması mı gerekecektir? Gerekmiyorsa ve mahkemenin mühlet kararından da anlaşılamıyorsa, konkordato komiserinin o işleme icazet vermesi yahut işlemi bizzat yapması mi gerekeceği konusunda bazı sorunların olduğu açıktır. Yine, mahkemenin son derece detaylı bir kısıtlama kararı vermiş olmasına rağmen, bazı yetkileri kısıtlamadığı durumda, bunun bilinçli olarak mı yapıldığı varsayılacaktır? Tüm bunlar bir kenara bırakıldığında, komiserin borçlunun faaliyetlerine nezaret etme yükümlülüğü bulunduğundan, bu yükümlülügüün sinırının belirlenmesi gerekecektir. Kanımızca, borçlunun tasarruf yetkisi Kanun'a göre belirli ölçüde kısıtlansa da, noter dairesi gibi devlet kurumlarında ve diğer merciler önünde hukuki güvenliğin sağlanması bakımından mahkemelerin verecekleri tasdik kararının daha özenli olması gerekir. Hangi yetkilerin kısıtlandığının açık açı belirtilmesi ya da nelerin yapılacağının tek tek yazılması mümkün olmasa da, özellikle işletmenin devamı için önem arz eden hususlar bakımından, ilgili sektörde veya şirket bünyesinde yapılan işlemlerin yoğunlaştığı alanlarda daha detaylı belirlemeler yapılabilir.

Borçlu, mahkemenin iznini almadan yapılması yasak işlemler yapar ya da komiserin ihtarlarına aykırı davranışlar sergilerse, mahkemece, borçlunun malları üzerindeki tasarruf yetkisinin kaldırılması söz konusu olabilir ${ }^{30}$. Yine, mahkeme, borçlunun bu davranışları sebebiyle İcra ve İflas Kanunu'nun 292. maddesi uyarınca konkordato talebini reddedebileceği gibi, iflasın açılmasına da karar verebilir (İ̈K m.297, III; Pekcanıtez vd., 2019: 471; Atalı vd. 2020: 665).

Burada, konkordato mühletinin kaldırılmasını kimlerin isteyebileceği hususunda bir sınırlamaya gidilmediği, alacaklıların ve komiserin evleviyetle bu yetkiye sahip olduklarını ifade etmek gerekir (Tanrıver- Mühletin Kaldırılması, 2005: 321-322).

\footnotetext{
${ }^{30} \mathrm{Bu}$ hüküm de, konkordatonun başarısızlıkla sonuçlanmaması adına, olumsuz sonuçları yumuşatmak amacıyla 4949 sayılı Kanun ile getirilmişti (Tanrıver- 4949 sayılı Kanun, 2005: 359).
} 
Borçlunun, kendi faaliyet alanıyla ilgili olan iş ve işlemlerde, Kanun'la yapması yasaklanmış işleri yapıp yapamayacağı konusunda bir açıklık mevcut değildi (Tanrıver- Konkordatonun Islahı, 2005: 342-343). Ancak, madde metninden anlaşıldığı üzere, komiserin nezareti olduğu sürece, eski Kanun'dan farklı olarak, borçlunun kendi işletmesiyle ilgili faaliyetlerine devam edebilmesi ve yasak işlemlerle karşılaşmaması söz konusu olacaktır (Tanrıver- 4949 sayılı Kanun, 2005: 360; Ercan, 2009: 221).

İcra ve İflas Kanunu'nun 297. maddesinin dördüncü fikrasında, hem borçlunun mahkemenin izniyle yaptığı, yapacağ işlemlerin hem de mahkemenin izni olmadan yapılan işlemlerle mahkemenin uyguladığı yaptırımların 288. madde uyarınca ilân edileceği ve ilgili yerlere bildirileceği hüküm altına alınmıştır (Tanrıver, 1993: 79).

\subsubsection{Borçtan Birlikte Sorumlu Olan Kişiler Bakımından}

Konkordato mühletinin bir diğer sonucu ise, borçtan birlikte sorumlu kişilere karşı olan etkisidir. Doktrinde de ifade edildiği üzere, 294. maddede düzenlenen takip yasağı, sadece borçluyu kapsamakta, yani borçlu ile birlikte müştereken borçlu konumunda bulunanları ve varsa kefili kapsamamaktadır (Atalı vd. 2020: 668; Altay, 2004: 278; Kuru, 2016: 688; Coşkun, 2016: 4868; Akil, 2019a: 230; Sarısözen, 2021: 322-323).

\section{KONKORDATO MÜHLETİ VERILMESINDEN SONRA YAPILACAK IŞ VE İSLEMLER}

\subsection{Defter Tutulması ve Rehinli Malların Kıymetinin Takdiri (İIK m.298)}

Defter tutulması ve rehinli malların kıymetinin takdiri başlıklı İcra ve İflas Kanunu'nun 298. maddesi, konkordatonun tasdikinden önce, komiser tarafından yapılacak ön hazırlık evresine ilişkindir ve belki de bu evrenin en önemli işlerinden birisidir. Buna göre komiser, görevlendirilmesinden sonra, borçlunun sahip olduğu malların bir defterini yapar ve malların kıymetlerini belirler. Bu yapılırken borçluya ait malvarlığının piyasadaki rayiç değerleri ve işletmenin faaliyetindeki değerinin esas alınması gerekir ve icap ederse, komiserin bilirkişiden destek alması da mümkündür (Türkoğlu, 2019: 110). Komiser tarafından belirlenen malların başka yerde bulunanları için, ilgili yer icra dairesinden hukuki destek istenir ve kıymet takdiri yaptırılır.

Komiserin rehinli malların değerlemesini yaptıktan sonra, varsa itirazlarının alınması için alacaklıların incelemesine imkan vermesi gerekir. Bu itibarla kıymet takdiri kararı, alacaklılar toplantısının yapılmasından önce, rehinli alacaklılara ve borçluya, yazılı bir biçimde bildirilir (İ̈K m.298, II). Bu hükmün getiriliş amacı, rehinli malların değerlerinin tam olarak belirlenmesi ve rehin hakkı sahibi alacaklıların rehinle temin edilen alacak miktarını aşan alacaklarını konkordato projesi kapsamında talep edebilmelerinin sağlanmasıdır (Türkoğlu, 2019: 112-113).

Rehinli alacaklılar ve borçluya kıymet takdirinin bildiriminden itibaren; diğer ilgililere ise öğrenme tarihinden itibaren yedi gün içerisinde, masrafların önceden ödenmesi şartıyla rehinli malların kıymet takdirlerinin yeniden belirlenmesini talep etme hakkı tanınmıştır. Bu talebin yöneltileceği merci ise ilgili asliye ticaret mahkemesidir. Alacaklıların başvurusu üzerine yapılacak yeni kıymet takdiri sonucunda ortaya çıkan miktar, "kayda değer" bir nitelik taşıyorsa, alacaklı, bu itiraz için yaptığı masrafları borçludan isteyebilir. Bu hükmün kıymet takdirini yapan/yaptıran komiser olması ve borçlunun herhangi bir katılımı 
olmaması sebebiyle hakkaniyete aykırı olduğu doktrinde haklı olarak ileri sürülmüştür (Türkoğlu, 2019: 113).

Tutulacak defterde, aktiflerin ve pasiflerin kolayca karşılaştırılabilmesine olanak sağlayacak şekilde, açık ve düzenli bilgiler yer almalı, olabildiğince, tüm malların tespit edilmesi gerekmektedir (Kuru, 2016: 690-691; Balc1, 2007: 179-180).

Tasarı metninde yer almayıp, Genel Kurul'da eklenen son fikra ise, kıymet takdirinin belirli kişilere özgülenmesini konu almaktadır. Şöyle ki, rehinli taşınmaz malların 298. madde kapsamında yapılacak değerleme işlemi, 6362 sayılı Sermaye Piyasası Kanunu uyarınca gayrimenkul değerleme uzmanlığı lisansı ile yetkilendirilen kişilere yaptırılabilir. Kanımızca, buradaki belirleme sınırlayıcı ve kesin olmayıp, örnekleyici niteliktedir.

\subsection{Alacaklıları Alacaklarını Bildirmeye Davet (İIK m.299)}

Alacaklılar kurulunun kesin mühlet kararıyla birlikte oluşturulmasına ilişkin İcra ve İflas Kanunu'nun 289. maddesinin dördüncü fıkrası ile alacaklıların alacaklarını bildirmeye davet edilmesi ve alacaklılar toplantısının yapılmasını öngören İcra ve İflas Kanunu'nun 299 ve 301. maddeleri dışında kesin mühletin hukuki sonuçlarıyla geçici mühletin hukuki sonuçları arasında bir fark bulunmamaktadır (Türkoğlu, 2019: 60).

Alacaklıların alacaklarını bildirmeye davet edilmesine ilişkin 299. maddeye göre, İcra ve İflas Kanunu'nun 288. maddesinde yer alan ilana ilişkin gerekliliklerin yerine getirilmesiyle, ilân tarihinden itibaren onbeş gün içinde alacaklılar, alacaklarını bildirmeye davet edilirler (İ̈K m.299, c.1). Bu ilanın amacı, konkordatonun amacına ulaşabilmesini temin etmektir. Ayrıca, ilânın birer örneği, adresi bilinen alacaklılara da posta vasıtasıyla gönderilir. Bu da alacaklılar yararına getirilmiş bir düzenleme olup, şayet alacağı bilançoda açıkça mevcut değilse, bir alacaklının, bu süre içerisinde alacağını bildirmemesi halinde, konkordato projesinin görüşmelerine kabul edilmesi mümkün değildir (İIK m.299, c.son).

İcra ve İflas Kanunu'nun konkordatoya ilişkin birçok hükmünde kendisine atıf yapılan 288. maddede, ilanın ticaret sicil gazetesinde ve Basın İlan Kurumu'nun resmî sitesinde yapılacağına işaret edilmiştir. Uygulamada, ilanların farklı tarihlerde yapılması halinde, hangi mecrada yapılan ilan tarihinin esas alınacağına ilişkin sorunlar ortaya çıkmıştır. Yargıtay'ın önüne gelen bir uyuşmazlıkta, bu mercilerde bir gün arayla (farklı tarihlerde) ilan edilen konkordato tasdik kararına karşı başvurulacak kanun yoluna ilişkin sürenin başlangıcında, "ilanların farklı tarihlerde yapılmış olması halinde hangisine değer verileceğinin belirlenmemiş olması nedeniyle temyiz edenin lehine olan ilan tarihinin esas alınması" gerektiğinden, sonraki tarihli ilanın esas alınacağına hükmedilmiştir ${ }^{31}$. Buradan yola çıkarak, ilan usulünü belirleyen 288. madde hükmüne yapılan diğer atıflar bakımından bir değerlendirme yapmak gerekirse, bilhassa hak düşürücü sürelerin başlangıç tarihinin belirlenmesinde, hak talep eden yahut başvurucu konumunda bulunanın lehine olan tarihin esas alınması gerektiği sonucuna varılabilir.

Hangi alacaklıların alacaklarını bildirmesi gerektiğine ilişkin ise, vadesi gelen alacaklar, erteleyici koşula veya belirsiz vadeye tabi alacaklar, emre muharrer senet hamilinin alacağı,

\footnotetext{
31 Yargitay 23. HD., T.27.1.2021, E.2020/2159, K.2021/268. (https://lib.kazanci.com.tr/kho3/ibb/files/23hd-20202159.htm)
} 
yabancı para alacakları, alacağı paradan başka bir şey olan alacaklılar, takas ileri sürülmesi halinde, bakiye alacağı kalmış olanlar sayılabilir (Coşkun, 2016: 4879-4880).

\subsection{Alacaklar Hakkında Borçlunun Beyana Daveti (İIK m.300)}

Yukarıda işaret edilmiş süreç boyunca, hem alacaklıların hem de borçlunun menfaatlerinin gözetilmesi, bir anlamda borçlunun hapsedilmemesi, konkordato sürecinde kendisine yer bulmasına imkan tanınması için de bir takım düzenlemeler yapılmıştır. İcra ve İflas Kanunu'nun 300. maddesine göre, konkordato komiseri, aleyhine öne sürülen alacaklar hakkında beyanda bulunmak üzere, borçluyu davet eder. Komiser, alacakların gerçekten mevcut olup olmadığını, borçlunun beyanı, defterleri ve belgeleriyle birlikte değerlendirir. Yapacağı değerlendirme sonucunda, katılım süresinin bitiminden itibaren en geç yedi gün içerisinde bir rapor sunması beklenmektedir. Bu raporun içeriğinde, konkordatoya ilişkin tüm belgeler, konkordato projesinin akıbeti ve tasdikinin uygunluğu hakkındaki gerekçeli görüşleri bulunur (İ̈K m.300, c.son atfıyla İIK m.302, VIII).

Burada, komiser, borçlunun kabul ettiği alacakla ilgili bir şüpheye düşerse, bu düşüncesini de raporuna ekler ve talebin reddini ister (Coşkun, 2016: 4883).

\subsection{Alacaklılar Toplantısına Davet (İIK m.301)}

Konkordato mühleti içerisinde projenin hazırlanması, alacakların bildirilmesi ve incelenmesinin tamamlanmasıyla birlikte komiser, İcra ve İflas Kanunu'nun 288. maddesine göre yapacağı ilan vasıtasıyla konkordato projesinin müzakeresi için toplantıya, alacaklıları davet eder. Toplantı tarihi ile ilan tarihi arasında en fazla onbeş gün bulunmalıdır. Ayrıca, adresi belli olan alacaklılara da bu ilandan bir nüsha gönderilir (İIKK m.301).

\subsection{Alacaklılar Toplantısı ve Projenin Kabulü İçin Gerekli Çoğunluk (İİK m.302)}

Konkordato mühletinin verilmesi ve alacakların bildirilmesinden sonra, konkordatonun geleceği açısından en önemli aşamalardan birisi olan konkordato projesi ile borçlunun durumunun değerlendirildiği aşamadan önce konkordato komiseri bir rapor hazırlar ve borçlunun da hazır bulunduğu bir toplantıda, konkordato projesi değerlendirmeye alınır.

Konkordato komiserinin nezaret edeceği bu toplantıda, o güne kadar geçen süreç içerisindeki faaliyetler ve borçlunun malvarlı̆̆ının durumu hakkında bilgi verilir ve daha önce belirlenen gündem maddeleri ele alınır (Tanrıver ve Deynekli, 1996: 56; Kuru, 2016: 690691; Coşkun, 2016: 4884).

Konkordato projesi rehinli alacaklılar ve diğer alacaklılar tarafından ayrı ayrı müzakere edilip oylanacaktır. Kaydedilmiş rehinli alacakların üçte ikisini aşan bir çoğunluk tarafından imza edilen proje, rehinli alacaklılar bakımından kabul edilmiş sayılacaktır ve bu alacaklıların, takdir edilen kıymet çıkarıldıktan sonra, kalan bedel için hesaba dahil edilmeleri öngörülmektedir (İ̈K m.302, V; Rehinli alacaklılar için ayrı bir hesap yapılmaktadır: Yılmaz, 2014: 732). Proje diğer alacaklılar tarafından da müzakere edilecektir. Burada da konkordato projesinin kabul edilebilmesi için şu iki ihtimalden birisinin gerçekleşmesi gerekir:

- Alacaklarını kaydettirmiş olan alacaklıların ve alacakların yarısını aşan bir çoğunluğun kabul etmesi. 
- Kaydedilmiş olan alacaklıların dörtte birini ve alacakların üçte ikisini aşan bir oranın mevcudiyeti.

Oylamada sadece konkordato projesinden etkilenen alacaklılar oy kullanabilecek, İcra ve İflas Kanunu'nun 206. maddesinin birinci sırasında yazılı imtiyazlı alacakların alacaklıları ve borçlunun eşi ve çocuğu ile kendisinin ve evlilik bağı ortadan kalkmış olsa dahi eşinin anası, babası ve kardeşi alacak ve alacaklı çoğunluğunun hesabında dikkate alınmayacaktır ${ }^{32}$ (İ̈K m.302, IV; Y1lmaz, 2014: 732).

Konkordato projesi hakkındaki değerlendirmeler sonunda bir konkordato tutanağ1 hazırlanır ve olumlu ve olumsuz oylar belirtilerek imzalanır. Toplantının bitimini takip eden yedi gün içinde gerçekleşen katılımlar da kabul olunur (İ̈K m.302, VII; Tanrıver ve Deynekli, 1996: 57). Komiser, bu sürenin bitiminden itibaren en geç yedi gün içerisinde konkordato projesi hakkındaki gerekçeli raporunu, tasdike ilişkin görüşlerini de içerecek şekilde, konkordatoya ilişkin tüm belgelerle birlikte mahkemeye verir (İ̈K m.302, VIII).

\section{SONUÇ}

Konkordato, icra ve iflas hukukumuzda unutulmaya yüz tutmuş bir kurum konumundaydı. Ancak, 2018 yılında 7101 sayılı Kanun ile geniş ölçekte uygulanmaya başlamış güncel bir prosedür haline gelmiştir. Ticari hayatın devamı ve işletmelerin ayakta tutulabilmesi bakımından oldukça önem arz eden konkordato kurumu, konkordato talebinin yapılması ve mühlet verilmesine ilişkin kararla bir çok sonuç doğurur. Bu itibarla öncelikle geçici mühlet verilmesi, buna ilişkin süreçler ve geçici mühlet sonunda kesin mühlet kararına ilişkin süreçler kısaca anlatılmıştır. Bu mühlet kararlarının sonuçlarına geçilmeden önce, mühlet kararlarına karşı hangi hallerde kanun yollarına başvurulup hangi hallerde başvurulamayacağına işaret edilmiştir.

Esas çalışma konumuzu teşkil eden konkordato mühletinin verilmesinin ise, temelde, alacaklılar, sözleşmeler ve borçlu bakımından birtakım sonuçları mevcuttur. Eski düzenlemelere nazaran, doktrinde işaret edilmiş öneriler de dikkate alınarak, mühletin sonuçları daha açık bir biçimde hüküm altına alınmış, takas, faiz gibi tartışmalı konulara açıklık getirilmiş, geçici mühlet kararının sonuçları bağlamında kesin mühlete atıf yapılarak, uygulama birliğine katkı sağlanmıştır. Konkordato mühletinin sonuçları bakımından, geçici mühlet, kesin mühletin sonuçlarını doğuracağından (İK m.288, I), her iki mühlet süreci ayrı ayrı ele alınmamıştır.

Öncelikle konkordato mühletinin alacaklılar bakımından sonuçları incelenmiş, Buna göre;

- Mühlet içinde borçlu aleyhine, hiçbir takip yapılamaz ve daha önceden başlamış takipler durur, ihtiyati tedbir ile ihtiyati haciz kararları uygulanamaz. Ancak, İcra ve İflas Kanunu'nun 206. maddesinin birinci sirasinda yazılı imtiyazlı alacaklar, bu kuralın istisnasıdır ve bunlar hakkında haciz yoluyla takip başlatılabileceği gibi, eski takiplere de devam edilebilir. Takip yasağından ne anlaşılması gerektiği hususunda ise, sırf icra takip işlemlerinin değil, doğrudan "takip talebinin" başlatılamaması gerektiği kanaatine varılmıştır.

\footnotetext{
32 (Bu yöndeki değişiklik önerisi için bkz.: Tanrıver- 4949 sayılı Kanun, 2005: 366-367).
} 
- Takas beyanında bulunulması mümkündür ve bu talep hem alacaklı hem de borçlu tarafından yapılabilmelidir.

- Hacizli mallar satılamayacak, satılmışsa elde edilen gelir, öncelikle alacağını sıra cetveline yazdırmış alacaklılar arasında paylaştırılır.

- Konkordato mühleti içerisinde, borçluya karşı yeni davaların açılabilmesinin ve açılmış davalara devam edilmesinin önünde herhangi bir engel yoktur.

- Konusu para olmayan alacaklar, komisere, alacaklı tarafından para alacağı şeklinde bildirilir ve onaylanmış konkordato projesi engel değilse, kesin mühletin verildiği tarihten başlayarak rehinle temin edilmemiş her türlü alacağa faiz işlemesi duracaktır.

- Rehinle temin edilmiş olan alacaklar bağlamında rehnin paraya çevrilmesi yoluyla takip başlatılabilir ve önceki takiplere devam edilebilir.

- Konkordato talebinden önce ya da konkordato komiserinden izin alınmadan, mühlet içerisinde doğmuş tüm alacaklar, konkordatonun bağlayıcı hale geldiği andan itibaren konkordato projesine tabi olur.

Konkordato mühletinin sözleşmeler bakımından sonuçları;

- Sözleşmenin diğer tarafının konkordato projesinden etkileniyor olması dikkate alınmaksızın, sözleşmelerin devamının esas olduğu. Borçlunun tarafı olduğu ve konkordatonun amacına ulaşmasını engelleyebilecek "aşırı külfetli" sürekli borç ilişkilerinin komiserin uygun görüşü ve mahkemenin izniyle istenildiğinde sona erdirilebileceği,

- Konkordato mühleti verilmesi ile borçlunun müeccel borçlarının, muaccel hale gelmeyeceği,

- Hizmet sözleşmelerinin, diğer sürekli borç ilişkisi doğuran sözleşmeler gibi feshedilmelerinin kanunen yasaklandığı,

şeklinde ifade edilebilir.

Konkordato mühletinin borçlu bakımından sonuçları şunlardır;

- Kural olarak borçlu tasarruf yetkisine sahiptir ve ticari hayatını devam ettirebilir. Ancak, geçici mühlete ilişkin kararın verilmesinden itibaren borçlunun malvarlığı üzerindeki tasarruf yetkisi mahkemece sınırlandırılabilir; bazı işlemlerde konkordato komiserine tam yetki verilmesi ve bazı işlemlerde de izninin alınmasına hükmedilebilir. Bu yapılırken de, gelecekte çıkması muhtemel sorunlar düşünülerek, tüm ihtimallerin gözetilmesi ve şablon şeklinde mühlet kararı verilmesinden kaçınılmalıdır.

- Borçlunun, mühlet kararının verilmesinden sonra, mahkemenin izni olmaksızın rehin tesis etmesi, kefil olması, ivazsız tasarruflarda bulunması, işletmesinin faaliyetinde önemli bir konumda bulunan taşınırı ve taşınmazını devretmesi ile takyit etmesi yasaklanmıştır.

- İcra ve İflas Kanunu'nun 297. maddesinin ikinci fıkrasında yer alan "işletmenin faaliyetinin devamı için önem arz etme" kavramının, uygulamada açıklığa kavuşturması, borçlunun yapıp yapamayacağı işlemlerin belirlenmesi bakımından önemlidir. Yine, 290. maddenin (b) fıkrasında komisere verilen "borçlunun faaliyetlerine nezaret etme" kavramının uygulama alanının belirlenmesindeki güçlüğe dikkat çekmek gerekir. 
- Takip yasağı, sadece borçluyu kapsamakta, yani borçlu ile birlikte müştereken borçlu konumunda bulunanları ve varsa kefili kapsamamaktadır.

Mühlet verilmesinin sonrasında atanan geçici komiser/konkordato komiseri, alacakların yazılması ile gerekli bilgi ve belgelerin incelenerek defter tutulması, rehinli malların kıymetlerinin belirlenmesi ve konkordato projesiyle ilgili diğer işlere nezaret edecek, mahkemece verilen yönetim ya da gözetim yetkisini kullanarak onay verme görevini ifa edecektir. Bu itibarla alacaklıların alacaklarını bildirmeye davet edilecek, borçlunun alacaklar hakkında beyana daveti, alacaklılar toplantısına davet ile konkordato projesinin kabulü için gerekli çoğunluğun sağlanması için oy kullanılacaktır. Mahkemenin esas olarak işlev göreceği aşamada ise, mühlet verilmesinden konkordatonun tasdikine kadar geçen süreçte varsa itirazlar incelenecek, komiserin görüşü doğrultusunda konkordato talebi hakkında bir karar verilecektir.

\section{KAYNAKÇA}

Akil C, (2019). “Konkordato Mühletinin Alacaklılar Bakımından Sonuçları (28.02.2018 Tarih ve 7101 sayılı Kanunla Yapılan Değişikliklere Göre)". Türkiye Barolar Birliği Dergisi, 141, s.227-252. (Akil, 2019a)

Akil C, (2019). "Konkordato Prosedürü Çerçevesinde Sürekli Borç İlişkilerinin Feshi”. Türkiye Barolar Birliği Dergisi, 143, s.221-233. (Akil, 2019b)

Altay, S. (2004). Konkordato ve Yeniden Yapılanma Hukuku, C.I-II, İstanbul.

Arslan, R./Yılmaz, E./Taşpınar Ayvaz, S./Hanağası, E. (2020). İcra ve İflâs Hukuku, 6. Baskı. Ankara: Yetkin Yayınları.

Aslanoğlu, S./Cengiz, S. (2021). “Konkordato Kurumunda Kesin Mühlet: Alacakl1, Borçlu ve Sözleşmeler Açısından Sonuçlarının Değerlendirilmesi". Ekonomi İşletme Siyaset ve Uluslararası İlişkiler Dergisi (JEBPIR), 7(1), s. 38-67.

Atalı, M. (2018). “Konkordatoda Kesin Mühlet ve Sonuçları”, 7101 Sayılı Kanunla Konkordato ve Elektronik Tebligat Konularında Getirilen Yenilikler, 4 Mayıs 2018, İstanbul, s.85-110.

Atalı, M./Ermenek, İ./ Erdoğan, E. (2020). İcra ve İflâs Hukuku, 3. Bask1. Ankara: Yetkin Yayınları.

Aydemir, E. (2015). Konkordato Sermaye Şirketleri ve Kooperatiflerin Uzlaşma Suretiyle Yapılandırılması. Ankara: Seçkin Yayıncılık.

Balc1, Ş. (2007). Hukukunda Konkordato. İzmir: Seçkin Yayıncılık.

Budak, A. Cem/Tunç Yücel, M. (2015). "İflas, Tasarrufun İptali Davası ve Konkordato ile İlgili 2013 Tarihli İsviçre İcra ve İflas Kanunu Değişiklikleri”, MİHBİR 13. Antalya Toplantısı, s.17-38.

Coşkun, M. (2016). Açıklamalı-İçtihatlı İcra ve İflas Kanunu, Cilt IV, 5. Baskı. Ankara: Seçkin Yayincilik.

Duran, R. (2020). Konkordato Mühleti ve Alacaklılar Bakımından Sonuçları. Ankara Yıldırım Beyazıt Üniversitesi Sosyal Bilimler Enstitüsü Özel Hukuk Ana Bilim Dalı Yayınlanmamış Yüksek Lisans Tezi. Ankara. 
Ercan, İ. (2009). İcra ve İflas Hukukunda Mal Varlı̆̆ının Terki Suretiyle Konkordato. Konya: Mimoza.

Eren, F. (2014). Borçlar Hukuku Genel Hükümler, 17. Bası. Ankara: Yetkin Yayınları.

Eren, F. (2014). Borçlar Hukuku Özel Hükümler. Ankara: Yetkin Yayınları.

Ermenek, İ./ Kartal, B. (2020). Konkordatonun Amacı Kapsamında COVID-19 Salgınının Sürekli Borç İlişkilerinin Feshine Etkisi. İstanbul Hukuk Mecmuası, 78 (2), s. 485-516.

https://lib.kazanci.com.tr/kho3/ibb/anaindex.html

Kale, S. (2015). "İflas İçi Adi Konkordato Uygulamasında Ortaya Çıkan Bazı Sorunlar", MIHBİR 13. Antalya Toplantısı, s.271-286.

Kuru, B. (2016). İstinaf Sistemine Göre Yazılmış İcra ve İflâs Hukuku, İstanbul: Legal.

Özekes, M. (2018). Konkordatoya Başvuru ve Geçici Mühlet Kararı. 7101 Sayılı Kanunla Konkordato ve Elektronik Tebligat Konularında Getirilen Yenilikler (Ed. Muhammet Özekes) s.43-83. İstanbul: Oniki Levha Yayınları.

Pekcanıtez, H. (2020). 2279 sayılı Cumhurbaşkanı (Fevkalâde Mühlet) Kararı ile 7226 Sayılı Kanunun Geçici 1. Maddesinin Birlikte Değerlendirilmesi. Lexpera Blog. (https://blog.lexpera.com.tr/2279-sayili-karar-ile-7226-sayili-kanunun-birliktedegerlendirilmesi/)

Pekcanitez, H./Erdönmez, G. (2018). “7101 sayılı Kanunla Yürürlüğe Giren Konkordato Hükümlerinin Değerlendirilmesi". Bankacılar Dergisi, 105, s.108-156.

Pekcanıtez, H./Erdönmez, G. (2018). 7101 Sayılı Kanun Çerçevesinde Konkordato. İstanbul: Vedat Kitapçılık. (Pekcanıtez ve Erdönmez, Kitap)

Pekcanitez, H./Atalay, O./Sungurtekin Özkan, M./Özekes, M. (2019). İcra ve İflâs Hukuku Ders Kitabı, 6. Bası. İstanbul: Seçkin Yayıncılık.

Saraç, Ş. (2019). 7101 Sayılı Kanun Çerçevesinde Konkordato. Ankara. (http://web2.ebaro.web.tr/uploads/41/032018/15.03.2019\%20\%20YEN\%C4\%B0\%20KONKORDATO\%20HUKUKU.pdf)

Sarıözen, M. S. (2021). Konkordato, 5. Baskı. Ankara: Yetkin Yayınları.

Simil, C. (2020). Konkordato Mühletinin Borçlu Bakımından Sonuçları. İstanbul: Oniki Levha Yayınları.

Şahin, Ç. S. (2020). Amerikan Hukuku ile Karşılaştırmalı Olarak Konkordato Mühletinin Alacaklılar Yönünden Sonuçları. Galatasaray Üniversitesi Sosyal Bilimler Enstitüsü Özel Hukuk Ana Bilim Dalı Yayınlanmamış Yüksek Lisans Tezi. İstanbul.

Tanrıver, S. (1993). Konkordato Komiseri. Ankara: Yetkin Yayınları.

Tanrıver, S. (2005). “Konkordato Prosedürünün Islahı ile İlgili Bazı Düşünceler”, MakalelerimI (1985-2005), Ankara, s.337-346).

Tanrıver, S. (2005). “4949 sayılı İcra ve İflâs Kanunu'nda Değişiklik Yapılmasına Dair Kanun'un Adi Konkordato ile İlgili Hükümlerde Getirmiş Olduğu Değişikliklerin 
Tespiti ve Değerlendirilmesi", (Makalelerim-I (1985-2005), Ankara, s. 347-370. (Tanrıver- 4949 sayılı Kanun)

Tanrıver, S. (2005). "Konkordato Mühletinin Kaldırılması", (Makalelerim-I (1985-2005), Ankara s. 317-324). (Tanrıver- Mühletin Kaldırılması)

Tanrıver, S./ Deynekli, A. (1996). Konkordatonun Tasdiki. Ankara: Yetkin Yayınları.

Taşpınar Ayvaz, S. (2005). İcra-İflâs Hukukunda Yeniden Yapılandırma. Ankara: Yetkin Yayınları.

Türkoğlu, T. (2019). Adi Konkordatoda Kesin Mühlet ve Hukuki Sonuçları. Bahçeşehir Üniversitesi Sosyal Bilimler Enstitüsü Özel Hukuk Ana Bilim Dalı Özel Hukuk Bilim Dalı Yayınlanmamış Yüksek Lisans Tezi. İstanbul.

Uyar, T. (2019). “Kesin Konkordato Mühletinin Alacaklılar Bakımından Sonuçları İ̇K m.294". Ankara Barosu Dergisi, 2, s.151-175.

Uyar, T. (2019). Yeni Konkordato Hukukumuzun Temel İlkeleri. Ankara: Türkiye Barolar Birliği Yayınları.

Yılmaz, E. (2014). "İflâs ve konkordato Uygulamasılyla İlgili Bazı Sorunlar Üzerine Düşünceler" Makaleler (1973-2013), Cilt I, Ankara. s.725-738.

Yılmaz, E. (2016). İcra ve İflâs Kanunu Şerhi. Ankara: Yetkin Yayınları. 